Joanna I. Cel

\title{
KWESTIA PORY ODPRAWIANIA RYTUAŁÓW W ŚWIETLE TZW. GRECKICH PAPIRUSÓW MAGICZNYCH*
}

W OPISACH RYTUA£ów w tzw. Papyri Graecae Magicae (PGM), ${ }^{1}$ na który to zbiór składają się również teksty demotyczne $(P D M)$, wielokrotnie można natknąć się na wskazówki, w jakim miejscu, w jakim stroju, a czasem nawet w jakiej pozycji należy podejmować się poszczególnych czynności. ${ }^{2}$ Zalecenia dotyczą niejednokrotnie również rodzaju składanych ofiar oraz sposobu wykorzystania (również dokładnie określonych) przygotowanych wcześniej

* Dziękuję prof UW dr. hab. Pawłowi Janiszewskiemu, promotorowi pracy dyplomowej, na podstawie której powstał ten artykuł, za wszelką pomoc i uwagi. Kieruję również podziękowania do dr Magdaleny Popiołek za uwagi translatorskie.

${ }^{1}$ Opieram się na wydaniach: K. Preisendanz (red.), Papyri Graecae Magicae. Die Griechischen Zauberpapyri. Durchgesehen und herausgegeben von A. Henrichs, t. 1-2, Stuttgart 1973-1974; H. D. Betz (red.), The Greek Magical Papyri in Translation Including the Demotic Spells, Chicago London 1986. Drugą z tych pozycji trzeba wyodrębnić, ponieważ jej redaktor wielokrotnie koryguje tekst źródłowy w stosunku do Preisendanza. Uzupełnia też wydanie o tłumaczenie tekstów demotycznych $(P D M)$ oraz tekstów greckich nieujętych w wydaniu Preisendanza.

${ }^{2}$ Na temat historii PGM patrz: R. GORDON, „Memory and authority in the magical papyri”, [w:] Historical and Religious Memory in the Ancient World, B. Dignas, R. R. Smith (red.), Oxford 2012, s. 145-180; W. BrasheAr, „The Greek Magical Papyri: An introduction and survey; annotated bibliography (1928-1994)", [w:] Aufstieg und Niedergang der römischen Welt, t. 2.18.5 (1995), passim. 
przedmiotów i wypowiadania poszczególnych słów i głosek w zaklęciach. Przy tego rodzaju dbałości o odpowiednie warunki oraz zachowania mające zapewnić skuteczność działania lub przychylność bóstwa dziwiłoby, gdyby w zaleceniach nie znalazły się wskazówki dotyczące czasu podejmowania konkretnych czynności.

Rzeczywiście, papirusy magiczne poruszają również kwestię czasu. Występują w nich instrukcje zawierające informacje, o jakiej porze należy wypowiedzieć zaklęcie, odprawić rytuał lub kiedy najlepiej poświęcić przedmiot. Wykorzystywane w PGM określenia czasu cechują się różnorodnością. Czasem wymagane jest, by daną czynność wykonać o wschodzie lub zachodzie Słońca, czasem potrzeba konkretnego dnia miesiąca, godziny lub warunków astronomicznych. Tym właśnie - porą podejmowania różnych działań magicznych - zajmę się w tym artykule.

Zagadnienie czasu w odniesieniu do magii lub rytuału nie cieszyło się szczególną uwagą badaczy. Szerszego opisu doczekały się zagadnienie dni pomyślnych i niepomyślnych oraz kwestie astrologiczne. Szerzej tematyką czasu w PGM zajmowała się wprawdzie Andrea Salayová, ${ }^{3}$ tekst jej jest jednak tylko pobieżną próbą omówienia zagadnienia. Salayová w swojej pracy zajęła się trzema kwestiami: jaki czas jest najlepszy dla działań magicznych, ile one trwają oraz co czas trwania mówi o znaczeniu rytuału.

Jeśli chodzi o porę odpowiednią dla rytuałów Salayová wymienia jako kategorie jedynie: odpowiedni czas w ciągu roku, w ciągu miesiąca, w ciągu tygodnia oraz w ciągu dnia. Podział wewnątrz miesiąca oraz dnia nie zostały jednak ujęte. Autorka analizuje obecność Księżyca w znakach zodiaku, brak jednak odniesień do pełni Księżyca, nowiu oraz pozostałych faz - są one jedynie wspomniane. Podobnie sprawa ma się z porami dnia - Salayová wymienia noc, wschód Słońca, wieczór i południe, ignoruje jednak konkretne godziny. ${ }^{4}$ Autorka nie zaliczyła też zawartych w instrukcjach sformułowań takich jak „przed pójściem spać” do wyznaczników pory dnia, co moim zdaniem należałoby przeanalizować. Nie zgadzam się również ze sposobem

${ }^{3}$ A. SAlayovÁ, „Aspects of temporality in Greek Magical Papyri”, Graeco-Latina Brunensia 23.1 (2018), s. 181-194.

${ }^{4}$ Komentując je: „Very often, the most suitable time is the sunrise, sometimes attested with the exact hour needed for the best results" - ibidem, s. 185 . 
przedstawiania liczby występujących w treści papirusów pór. Autorka przedstawiła jedynie, $w$ ilu zaklęciach pojawia się dane odniesienie. Biorąc pod uwagę, że kilkukrotnie w jednym papirusie pojawia się taka sama pora, ale mogąca odnosić się już do innego dnia, należałoby jednak przedstawić je poprzez liczbę wzmianek, a nie zaklęć. Np. wg Salayovej wschód - słusznie określony zarówno przez nią, jak i Williama Brasheara jako najbardziej odpowiedni dla magii według $P G M^{5}$ - pojawia się w dwudziestu dziewięciu zaklęciach, podczas gdy samych odniesień do wschodu i poranka jest około sześćdziesięciu. Ponadto Autorka skupiała się jedynie na częstotliwości występowania danych określeń dotyczących czasu, nie podjęła się zaś próby przyjrzenia się związkowi pory dnia z rodzajem wykonywanego rytuału. Wszystko to sprawia, że wciąż potrzebny jest dokładniejszy przegląd pór odpowiednich dla magii.

Przedmiotem poniższych badań jest moment, w którym odby-wało się działanie noszące znamiona magiczne - odprawienie rytuału, wypowiedzenie zaklęcia lub inne czynności im towarzyszące. ${ }^{6}$ Jeśli chodzi o samą definicję tego, czym jest magia, w literaturze poświęcono jej wiele miejsca. ${ }^{7} \mathrm{~W}$ celu ustalenia definicji magii oraz ostatecznego zaakceptowania lub zanegowania różnic pomiędzy nią a religią, podejmowane były wielokrotnie próby z użyciem różnych kryteriów. ${ }^{8}$ Rozróżnienie między nimi przysparza jednak

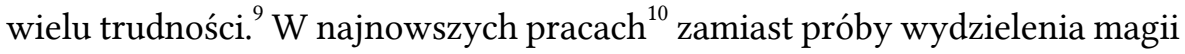

\footnotetext{
${ }^{5}$ Brashear, „The Greek Magical Papyri” (cyt. w przyp. 2), s. 3398.

${ }^{6}$ Terminy takie jak „działania magiczne”, „praktyki magiczne” oraz „rytuały” na potrzeby tego tekstu będą używane zamiennie.

${ }^{7}$ Patrz m.in: R. L. FowleR, „Greek magic, Greek religion”, Illinois Classical Studies 20 (1995), s. 1-22; F. Graf, Magic in the Ancient World, London 1997; P. Mirecki, M. Meyer, Magic and Ritual in the Ancient World, Religions in the Graeco-Roman World, Leiden 2002; Ch. A. PHAraone, D. Obbink, Magika Hiera. Ancient Greek Magic and Religion, Oxford 1991.

${ }^{8}$ Brashear, „The Greek Magical Papyri” (cyt. w przyp. 2), s. 3398.

${ }^{9}$ J. Ch. Balty (red.), Thesaurus Cultus et Rituum Antiquorum (ThesCRA), 3: Divination, Prayer, Veneration, Hikesia, Asylia, Oath, Malediction, Profanation, Magic Rituals and Addendum to vol. 2: Consecration, Los Angeles 2005, s. 286.

${ }^{10}$ Ukazał się niedawno tekst streszczający bieżący stan sporu: J. E. SANzo, „Deconstructing the deconstructionists: A response to recent criticisms of the rubric", [w:] Ancient Magic: Then and Now, A. Mastrocinque, J. E. SAnzo (red.), Sttutgart 2020, s. 25-46.
} 
z religii albo wskazywania głównych cech, które je różnią, podjęto się definiowania magii na nowy sposób: poprzez używanie alter-natywnego terminu „moc rytualna”. Uwalnia to koncepcję magii od specyficznych dla danego miejsca i czasu aspektów kultury oraz od tła historycznego i społecznego. ${ }^{11}$ Mając w pamięci koncepcje „mocy”, na potrzeby artykułu używam jednak starszej terminologii związanej z magią. Na wzór Christophera A. Faraone uznaję jednocześnie magię za „set of practical devices and rituals used by the Greeks in their day-to-day lives to control or otherwise influence supernaturally the forces of nature, animals, or other human beings" ${ }^{12}$ Bazując zaś na korpusie tekstów uznanych za magiczne przez dotychczasowych wydawców, zaliczam do badania większość opisywanych przez nie czynności.

\section{WSCHÓD I PORANEK}

Wschód jest porą, o której wzmianki występują w PGM najczęściej. Odnoszą się one do wykonywania różnego rodzaju czynności, np. do recytowania hymnów i wypowiadania zaklęć lub do elementów składowych większych rytuałów.

Działanie magiczne wykonywane o wschodzie nie musiało być częścią żadnego skomplikowanego obrzędu. Przykładami na to są chociażby ustępy z PDM xiv, związane z podawaniem komuś specjalnego napoju. Pierwszy (PDM xiv 563-574) w większości składa się z treści zaklęcia, które ma sprawić, by $\mathrm{z}$ osoby, która wypiła truciznę, uszedł jad. Zaklęcie należy wypowiedzieć siedmiokrotnie nad kielichem wina $\mathrm{z}$ dodatkiem świeżej ruty. Tak przygotowany napój należy o świcie podać osobie otrutej (wersy 573-574). Drugi ze wspomnianych passusów znajduje się w części papirusu, w której znaleźć można różne instrukcje odnoszące się do spraw ginekologicznych oraz antykoncepcji: PDM xiv 953-955 zaleca kobiecie wypić o świcie mieszankę piwa $\mathrm{z}$ wyciągiem z odpowiedniej rośliny na powstrzymanie krwawienia.

${ }^{11}$ D. Frankfurter, Guide to the Study of Ancient Magic, Leiden - Boston 2019, s. 605-607.

${ }^{12}$ Ch. A. Faraone, Ancient Greek Love Magic, Cambridge - London 2001, s. 15. 


\subsection{Post i milczenie}

Obydwa przedstawione passusy mają jeszcze jedną cechę wspólną wprowadzającą $\mathrm{w}$ dodatkowe zagadnienie towarzyszące różnym rytuałom odprawianym o poranku: zalecają wypicie leczniczego napoju przed jedzeniem. W wypadku tych fragmentów powstrzymanie się od jedzenia przed piciem leku można próbować tłumaczyć względami medycznymi - spożycie go na czczo może wpływać na siłę jego działania. W papirusach magicznych znajdują się jednak również zalecenia wstrzymania się rano od jedzenia niezwiązane z przyjmowaniem później specjalistycznych lub magicznych substancji (np. PGM III 282-409 zaleca w wersach 334-335 oczekiwać na wschód Słońca poszcząc) oraz ograniczenia polegające na zakazie rozmawiania z kimkolwiek przed wypełnieniem obrzędu.

PDM xiv 309-334 to w większej części skierowane do Thota zaklęcie mające zapewnić przychylność. Po tekście przeznaczonym do recytacji znajduje się instrukcja (wersy 330-334) odpowiedniego przeprowadzenia rytuału, która mówi odnośnie do zaklęcia: ${ }^{13}$ „recytuj (...) siedem razy przed Słońcem o świcie, zanim odezwiesz się do jakiegokolwiek człowieka”. Dalsza, końcowa część passusu, nakazuje oczyszczenie maści i nasmarowanie nią twarzy. Potem można udać się do jakiegokolwiek miejsca i przebywać wśród ludzi. Do tego zalecenia dodane zostało zapewnienie, że osoba przeprowadzająca rytuał zyska uznanie innych.

Znajdujący się bezpośrednio po tej partii PDM xiv 335-355 opisuje rytuał i zaklęcie mające zapewnić miłość kobiety. Przygotowania należy zacząć na dzień przed początkiem miesiąca księżycowego, a następnie prowadzić je przez siedem dni. Interesujący jest przede wszystkim wątek wypowiadania o świcie odpowiedniego zaklęcia. Tekst mówi bowiem (339-340) „powinieneś wypowiadać tę formułę do niej [ryby używanej do rytuału - JC] o świcie (...) zanim wyjdziesz z domu i zanim będziesz rozmawiał z jakimkolwiek człowiekiem na ziemi".

Podobne do powyższych zalecenia znaleźć można jeszcze m. in. w PGM VII 619-527. Ten, kto po trzymaniu podczas snu pod językiem kwiatu lwiej

\footnotetext{
${ }^{13}$ Grekę, jeśli nie wskazano inaczej, przywołuję za: Preisendanz, Papyri Graecae Magicae (cyt. w przyp. 1), Tekstów demotycznych nie cytuję w oryginale, podaję do nich własne thu-
} 
paszczy wstanie wcześnie i wypowie odpowiednie imiona bogów, zanim odezwie się do jakiegokolwiek człowieka, stanie się niewidzialny. Tego typu połączenie nakazu milczenia oraz świtu pozwala domyślać się pory wykonywania działań magicznych na podstawie instrukcji do nich, w których występuje jedynie pierwszy z tych elementów. Dlatego zaklęcie i voces z PGM III 263-275, które należy wypowiadać przed odezwaniem się do kogokolwiek, powinny być recytowane właśnie o poranku.

Wydaje się, że to właśnie zalecenie milczenia, jako formy czystości czy też wzmocnienia wypowiadanego zaklęcia, miałoby w tych przypadkach większe znaczenie dla rytuału niż jego faktyczna pora w ciągu dnia. Być może milczenie było analogią do zachowania rytualnej czystości przed kontaktem z bóstwem - albo pierwszym słowom wypowiadanym w ciagu dnia przypisywano szczególną moc. Wśród $P G M$ nie ma relacji sugerującej zachowywanie milczenia przez dłuższy czas po przebudzeniu. Wskazanie takie można odnaleźć za to w kontekście jedzenia, np. w PDM xiv 978-980 lub PGM III 410-423.

\subsection{Hymny i zaklęcia}

Wspomniane wyżej PDM xiv 309-334 oraz PDM xiv 335-355 są przykładami opisów, w których uregulowany jest czas odprawiania większych rytuałów lub ich elementów. Ważne w praktykach magicznych i często wykonywane o wschodzie było recytowanie hymnów lub $\lambda$ óyou. Matt Cohn, ${ }^{14}$ analizując papirus P. Mich. 3404 recto, w którym również występują treści magiczne, wspomina o występujących w $P G M$ trzynastu $^{15}$ zaklęciach wypowiadanych o wschodzie Słońca, z których jedenaście ma być wyraźnie wykorzystanych jako część większego rytuału. Grupę porannych zaklęć można jednak powiększyć: PGM XII 270-350 również podaje treść zaklęcia, które należy

maczenie wykonane po konsultacji z wersją angielską wg BETz, The Greek Magical Papyri (cyt. w przyp. 1).

${ }^{14}$ M. CоHN, „P. Mich. 3404 recto: An unpublished magical papyrus”, Zeitschrift für Papyrologie und Epigraphik 182 (2012), s. 243-244.

${ }^{15}$ PGM I 42-195; II 64-183; III 1-164; III 282-409; IV 154-285; IV 930-1114; IV 1926-2005; V 213-303; V 370-446; VI 1-47; VII 505-528; VII 981-993; XIII 225-260. 
wypowiadać o świcie, zwracając się w stronę Słońca. Ponadto w PGM XIII 646-734 znajduje się polecenie witania Heliosa o wschodzie przez siedem dni oraz wypowiadania w tym czasie imion bogów odpowiedzialnych za godziny i tygodnie - niewykluczone, że towarzyszyło temu również jakieś zaklęcie.

Do grupy magicznych formuł wypowiadanych rano dołącza również tekst ze wspomnianego P. Mich. 3404 recto. ${ }^{16}$ Po jednozdaniowej, zalecającej mówienie do wschodzącego Słońca, instrukcji, następuje kierowany do „wschodzącego boga” tekst z prośbą o jego przychylnośćc ${ }^{17}$. Tekst odpowiada strukturą tradycyjnemu hymnowi oraz innym $\lambda$ ó $\gamma$ or kierowanym o wschodzie do Słońca ${ }^{18}$. Czas wypowiadania zaklęcia bądź hymnu nie warunkuje jednak od razu, do jakiego boga ma być on kierowany. W PGM większość wypowiadanych o wschodzie formuł jest najprawdopodobniej kierowana do boga słonecznego, najczęściej Heliosa (miejscami Apollona), można jednak wskazać przykłady innych adresatów tych zaklęć. PGM IV 154-285 opisuje rytuał rozpoczynający się o wschodzie (trwający do południa) - adresatem recytowanego zaklęcia jest jednak Tyfon, identyfikowany również z Setem. W PGM V 370-446 wypowiadane o wschodzie zaklęcie jest z kolei skierowane do Hermesa. Nie dziwi to w kontekście całego opisywanego tu rytuału: na początku passusu występuje bowiem dokładny opis utworzenia figurki Hermesa. Jest to jednocześnie przykład obrzędu, dla którego wskazanie odpowiedniego czasu wykonania nie ogranicza się do pory dnia: figurkę tę należy bowiem wykonać $\mathrm{w}$ dniu, w którym Księżyc wstępuje w jeden z odpowiednich znaków zodiaku (Baran, Lew, Panna lub Strzelec). Zaklęcie do Hermesa ma być wypowiadane kilkukrotnie: wieczorem, po skonstruowaniu figurki, oraz następnego dnia o wschodzie Słońca. Zagadnienie zaklęć przeznaczonych do wypowiadania zarówno rano, jak i wieczorem zostanie poruszone w części pracy poświęconej zachodowi Słońca.

Zalecenia odnoszące się do czasu rytuałów są zazwyczaj krótkie. Można znaleźć passusy mówiące niewiele więcej, niż by użyć czegoś, „zanim

\footnotetext{
${ }^{16}$ Kilka hymnów do wschodu Słońca zostało również omówionych w: R. MERKELBACH, M. Tотті, Abrasax: Ausgewählte Papyri Religiösen und Magischen Inhalts, 1: Gebete [= Abhandlungen der Rheinisch-Westfälischen Akademie der Wissenschaften 17.1], Opladen 1990.

${ }^{17}$ CoHn, „P. Mich 3404”, s. 248 (cyt. w przyp. 14).

${ }^{18}$ Ibidem, s. 246.
} 
zobaczysz Słońce”"19 (PGM CXXII 1-55), czy też „I wziąwszy mleko z miodem wypij je przed wschodem Słońca"20 (PGM I 1-42). Jednak czasem zalecenia są bardziej szczegółowe. W PDM xiv 856-875 opisany jest rytuał zapytania z wykorzystaniem czystego rytualnie młodzieńca. Chłopca należy przyprowadzić przed Słońce i w odpowiednim momencie sprawić, by stanął na jego tle (wersy 856-860): „spraw, aby stanął na nowej cegle w momencie, w którym Słońce ma wschodzić, tak żeby pojawił się całkowicie w dysku”.

\subsection{Rytuał wtajemniczenia}

Bardzo szczegółowo do etapów pojawiania się Słońca na niebie o wschodzie odnosi się instrukcja z PGM IV 26-51. Opisuje ona rytuał wtajemniczenia

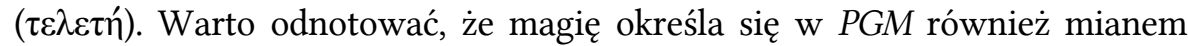

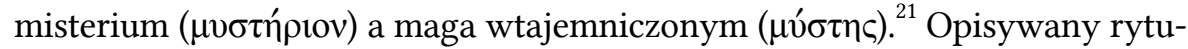
ał zaczyna się dokładnym ustaleniem uznanego za święte i oddalonego od normalnego świata ${ }^{22}$ miejsca oraz czasu jego przeprowadzenia (wersy 26-39):

Przed [wtajemniczeniem - JC] zachowaj czystość przez siedem dni. Trzeciego dnia miesiąca pójdź do miejsca, z którego ostatnio cofnął się Nil - zanim ktokolwiek przyjdzie na obszar, który był zalany - albo w każdym razie na miejsce, które było zalane przez Nil. Na dwóch cegłach stojących na swoich wąskich bokach rozpal ogień z drzewem oliwnym (to jest, z gałęzią z niego), gdy połowa Słońca jest nad horyzontem; ale przebiegnąwszy się wokół ołtarza, zanim pojawi się Słońce. Gdy dysk słoneczny jest w całości nad horyzontem odetnij głowę nieskazitelnego, całkowicie białego koguta, którego masz nieść pod swoim lewym ramieniem (przebiegnąwszy się wokół ołtarza, zanim pojawi się Słońce).$^{23}$

${ }^{19}$ 'ín $\pi$ jív ñ $\lambda$ iov według: W. BRASHEAR, „Ein Berliner Zauberpapyrus”, Zeitschrift für Papyrologie und Epigraphik 33 (1979), s. 261-278, na s. 263.

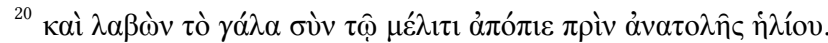

${ }^{21}$ H. D. Betz, „Magic and mystery in the Greek Magical Papyri”, [w:] Pharaone, Obbink, Magika Hiera (cyt. w przyp. 7), s. 249.

${ }^{22}$ S. I. Johnston, Hekate Soteira. A Study of Hekate's Roles in the Chaldean Oracles and Related Literature [= American Classical Studies 21], Atlanta 1990, s. 353.

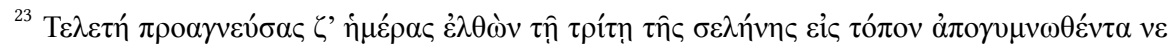


Dalsza część tekstu opisuje, w jaki sposób odciąć głowę kogutowi, po czym nakazuje wypić jego świeżą krew, pozbyć się ciała ptaka i oddalić się od miejsca rytuału. Daje też wskazówki, jak należy inicjację zakończyć po przebraniu się w nowe szaty.

Tekst wskazuje porę obrzędu bardzo jasno: należy odprawić go trzeciego dnia miesiąca, po siedmiodniowym okresie oczyszczenia, o wschodzie. Tego typu dokładne określenie czasu nie jest w PGM rzadko spotykane, wyjątkową szczegółowością autor instrukcji odznaczył się jednak, określając wykonanie kolejnych czynności w stosunku do stopnia ukazania się Słońca na hory-zoncie. Przed jego pojawieniem się należy obiec utworzony z cegieł ołtarz (zalecenie obiegnięcia ołtarza pojawia się dwukrotnie, być może z pomyłki kopisty, bo z dalszego opisu nie wynika, by był on szczególnie istotny dla rytuału). $\mathrm{W}$ momencie, gdy słońce wyłoni się w połowie, należy rozpalić ogień - tak szczegółowo określony czas tej czynności w tekście świadczącym o dobrym wykształceniu autora może być odniesieniem do powszechnego skojarzenia ognia ze słońcem. ${ }^{24}$ Właściwa, nie przygotowawcza, część rytuału odbywa się za to już w momencie, gdy Słońce pojawia się na niebie w całości.

Główna faza rytuału ma miejsce już po etapie przechodzenia Słońca, gdy jest ono w pełni obecne nad ziemią i nad wtajemniczanym. Jednak ten obrzęd wtajemniczenia ${ }^{25}$ wpisuje się $\mathrm{w}$ grupę rytuałów wykonywanych podczas wschodu, będącego rodzajem fazy liminalnej (przejście między nocą i dniem), co nabiera symboliki wprowadzenia do nowego stanu i wiedzy. ${ }^{26}$ Warto

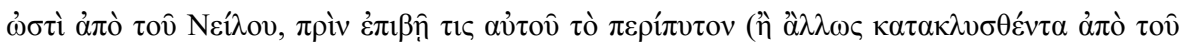

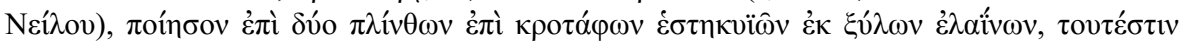

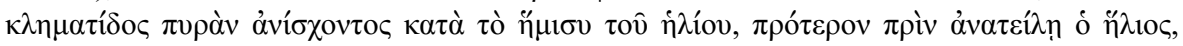

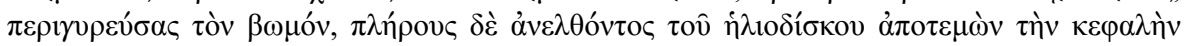

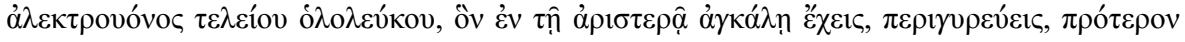

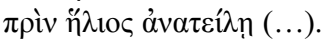

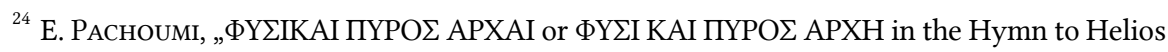
(PGM IV.939-948)", Zeitschrift für Papyrologie und Epigraphik 192 (2014), s. 104-107, na s. 105.

${ }^{25}$ Więcej o symbolu koguta, zob. Abd El-Mohse El-Khashab, "The cocks, the cat, and the chariot of the Sun”, Zeitschrift für Papyrologie und Epigraphik 55 (1984), s. 215-222, na s. 215-216.

${ }^{26} \mathrm{Na}$ znaczenie liminalności dla czasu odprawiania rytuałów zwracał uwagę Brashear w: W. M. BRASHEAR, „Zauberformular”, Archiv fur Papyrusforschung und verwandte Gebiete 36 (1990), s. 61-74; na temat czasu w magii patrz zwłaszcza s. 65-69. 
zauważyć, że miejsce odprawienia rytuału może dodatkowo podkreślać jego związek ze Słońcem - według Egipcjan bóstwo słoneczne było odpowiedzialne również za wylewy Nilu. ${ }^{27}$

\subsection{Zbieranie roślin}

Czasami to nie wschód jest podany jako czas, w którym dana czynność ma zostać wykonana. Kilkukrotnie pojawia się nawiązanie do czasu przed pojawieniem się Słońca. Są to zwykle momenty przygotowania do późniejszego rytuału. Świt bywa porą, przed którą należy działanie zakończyć, której należy się wystrzegać. Widać to na przykładzie zbierania roślin, które później staną się składnikiem magicznych lub medycznych receptur. Można trafić na odwołanie do rośliny zbieranej o wschodzie (piołun w PGM IV 2690), ale teksty poświęcające tej tematyce więcej uwagi zalecają zrywanie przed wschodem Słońca, tak jak w PGM IV 286-295 czy PGM IV 3172-3208.

PGM IV 2967-3006 nie zawiera żadnego odniesienia do wschodu Słońca, jednak tekst zawartego w nim zaklęcia daje dodatkowe potwierdzenie, że odpowiednia pora zrywania każdej rośliny ma znaczenie i niesie ze sobą wiarę we wzmocnienie działania zioła. Zielarz mówi bowiem (wersy 30003001): „Pozyskuję cię (...) zarówno w pomyślnej godzinie, jak i w pomyślnym dniu, który jest skuteczny dla wszystkich spraw". ${ }^{28}$ Kwestia dni pomyślnych i niepomyślnych jest bardziej złożona - dotyczyła nie tylko magii, ale również życia codziennego. W takim kontekście pojawiają się one m.in. w Pracach $i$ dniach Hezjoda oraz w wielu kalendarzach egipskich, które kontrolują na przykład to, czy w danym dniu można się kłócić, składać ofiary albo uprawiać seks. ${ }^{29}$ Dni pomyślne w PGM będą jeszcze poruszone w dalszej części tekstu.

Za treścią cytowanego passusu może stać przekonanie, że różne gatunki roślin mają różne pory, w których należy je zbierać, by móc $\mathrm{w}$ pełni

\footnotetext{
${ }^{27}$ Merkelbach, Totti, „Abrasax”(cyt w przyp. 16), s. 7.

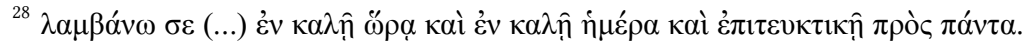

${ }^{29}$ Przykład takiego kalendarza: Abd El-Mohsen Bakir (red.), The Cairo Calendar No. 86637, Cairo 1966.
} 
wykorzystać ich właściwości, bądź też że istnieją dni, w których zbieranie roślin jest bardziej wskazane niż w inne. Źródła literackie sugerują zresztą, że przy zbieraniu magicznych ziół niezbędna jest obecność światła Księżyca. ${ }^{30}$

John Scarborough przyrównał zbieranie roślin do aktu kultowego, wiążącego się z przeświadczeniem maga o świętości istniejącej w każdej części rośliny, której naturalne działanie miało być wzmacniane w odpowiednim przekształceniu jej $\mathrm{w}$ środek działający ku celom człowieka. ${ }^{31}$ Egipcjanie przydawali roślinom moc boską, a niektóre uważano za atrybuty bogów. ${ }^{32}$ Bardziej zaawansowani w wiedzy astrologicznej posługiwali się skomplikowanymi wytycznymi podczas zbierania ziół: oczekiwali dnia i godziny przypisanych konkretnie do danej rośliny lub też okresu zwiększonego wpływu jej planetarnego patrona. ${ }^{33}$

\section{INNE PORY DNIA}

Jak zostało już zaznaczone, działania magiczne nie zawsze były skoncentrowane wokół wschodu Słońca: czasem wschód był momentem tylko jednej (równorzędnej lub nawet podrzędnej) z szeregu wykonywanych o różnych porach czynności. Dobrze widocznie jest to na przykładzie zaklęć wypowiadanych zarówno o wschodzie, jak i o zachodzie.

\subsection{Wschód i zachód}

PDM xiv 675-694 (PGM XIVc. 15-27) zawiera kilka odniesień do czasu. Opisuje procedurę wywołania u kogoś złego snu - z kontekstu można wnio-

${ }^{30}$ S. LunAIS, Recherches sur la lune, 1: Les auteurs latins de la fin des Guerres Puniques à la fin du règne des Antonins [= Études préliminaires aux religions orientales dans l'Empire romain 72], Leiden 1979, s. 218-225.

${ }^{31}$ J. Scarborough, „The pharmacology of sacred plants, herbs and roots”, [w:] Pharaone, Oввіnк, Magika Hiera (cyt. w przyp. 7), s. 157-158.

${ }^{32}$ E. PAсноuмi, „The religious and philosophical assimilations of Helios in the Greek Magical Papyri”, Greek, Roman, and Byzantine Studies 55 (2015), s. 391-413, na s. 406.

${ }^{33}$ T. BARton, Ancient Astrology, London - New York 1995, s. 191. 
skować, że chodzi o wywołanie śpiączki. Ważną częścią rytuału jest zaklęcie do Tyfona wypowiadane przed Słońcem. Do procedury potrzebna jest głowa osła. Należy ją umieścić naprzeciwko Słońca pomiędzy swoimi stopami. Powtórzyć to trzeba zarówno o wschodzie, jak i o zachodzie Słońca, recytując wówczas podane zaklęcie. Nie było to jednak działanie jednorazowe: aby uzyskać pożądany efekt wywołania snu, należało powtarzać rytuał przez cztery dni - codziennie zarówno rano, jak i wieczorem, w taki sam sposób. Siłę działania tej konkretnej procedury można modyfikować poprzez wydłużenie wykonywania rytuału do siedmiu dni i doprowadzić ofiarę do śmierci.

Inny rytuał odprawiany dokładnie o tych samych porach znajduje się w PGM VII 505-528. Do części obrzędowej wykorzystać trzeba dwa jajka. Na jednym z jajek należy napisać imię (przedstawione wcześniej w papirusie), z jego pomocą dokonać oczyszczenia. Następnie imię należy zlizać, a jajko zbić i wyrzucić. Drugie jajo, trzymane w prawej ręce, należy pokazać Słońcu o świcie. Dalej w tekście jest lakuna. Późniejsza część mówi, by po wykonaniu kilku odpowiednich ruchów oraz wypowiedzeniu siedmiokrotnie formuły rozbić drugie jajko, a następnie przełknąć jego zawartość. Ostatnie zdanie instrukcji nakazuje odprawianie rytuału przez siedem dni oraz recytowanie podanej formuły zarówno o wschodzie, jak i o zachodzie Słońca.

Nie jest jasne, czy cały obrzęd miał być wykonywany rano i wieczorem: przy założeniu, że tak, można domyślać się, że wówczas drugie z jaj należałoby pokazywać Słońcu również o zachodzie Słońca. Zwraca jednak uwagę inna rzecz: ponownie pojawia się zalecenie odprawiania rytuału przez siedem kolejnych dni. Wersy 505-506 z PGM VII zawierają też przywitanie z odpowiednimi demonami: „witaj (...), ty, demonie tego miejsca, i ty, obecna godzino, i ty, obecny dniu i wszystkie dni”. ${ }^{34}$ Cały rytuał jest również określony jako przepis na spotkanie $\mathrm{z}$ własnym ('íıৎ) demonem. Być może jednym $\mathrm{z}$ powodów zalecenia wykonywania rytuału przez siedem dni była chęć nawiązania odpowiedniego kontaktu z demonem każdego dnia tygodnia - bądź też z każdym z bóstw, od których imion wzięly się nazwy dni w kulturze greckiej. ${ }^{35}$

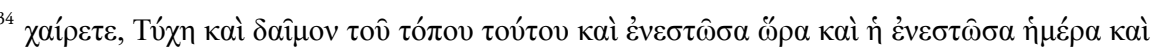

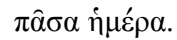

${ }^{35}$ Symbolika liczby siedem, zob: W. R. DAwson, „The number seven in Egyptian texts”, Aegyptus 8 (1927), s. 97-101, na s. 101-103; R. A. LAROche, „Popular symbolic/mystical numbers in antiquity", Latomus 54.3 (1995), s. 571.
} 
Nie wszystkie rytuały odnoszące się zarówno do wschodu, jak i zachodu zostawiają między porankiem a wieczorem przerwę. Np. w PDM xiv 636-669 elementem łączącym działania magiczne wykonywane o wschodzie i zachodzie jest namaczanie skarabeusza mlekiem. O wschodzie Słońca należy siedmiokrotnie wypowiedzieć zaklęcie do skarabeusza znajdującego się w dłoni, następnie włożyć owada i kawałki drzewa oliwnego do mleka. Zostawionego do wieczora skarabeusza należy wyjąć, odpowiednio rozłożyć na piasku i suszyć przez cztery dni.

W wypadku tego rytuału odczekanie z wyjęciem owada do wieczora może mieć znaczenie nie tyle symboliczne, co techniczne: być może uważano, że dopiero po całym dniu skarabeusz będzie odpowiednio nasączony substancją. Nawiązanie do wieczora, mimo że występujące przy tym rytuale, tym bardziej wydaje się pozbawione większego znaczenia dla obrzędu, że w dalszej części tekstu została przedstawiona alternatywna procedura niewymagająca topienia skarabeusza. W tej wersji, po wypowiedzeniu zaklęcia o wschodzie, owada należy ugotować - jedynym utrudnieniem zastosowania tej skróconej procedury jest to, że można jej użyć jedynie trzeciego dnia miesiąca lunarnego.

Są rytuały, w których wyjątkowo ważne jest bycie wieczorem w odpowiednim miejscu - jest tak chociażby w przypadku opisywanego przez PGM

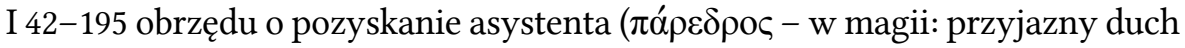
lub asystujące bóstwo ${ }^{36}$ ), którego tekst określa potem mianem boga lub

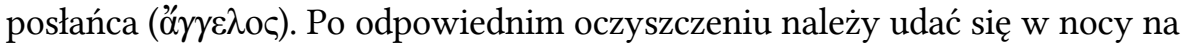
dach. Tekst w tym miejscu (wersy 55-65) ma kilka lakun, więc przebieg rytuału nie jest jasny: najpierw instrukcja mówi, by wypowiedzieć pierwsze zaklęcie, gdy tarcza Słońca znika - w kolejnej części zdania jest jednak odniesienie do zaklęcia wypowiadanego podczas wschodu Słońca. Nie można wykluczyć, że coś miało trwać całą noc, ani też, że rano po prostu należało wrócić na to samo miejsce, by wypowiedzieć zaklęcie jeszcze raz. Nie dziwiłoby to zresztą w obliczu dalszych zaleceń instrukcji. Wersy 70-71 mówią: „Ale wieczorem wszedłszy na swój dach ponownie i stanąwszy całkowicie w świetle bogini [Selene - JC] przemów do niej tym hymnicznym zaklęciem" ${ }^{37} \mathrm{~W}$ tym długim

\footnotetext{
${ }^{36}$ LSf, s.v. $\pi \alpha ́ \rho \varepsilon \delta \rho о \varsigma$.

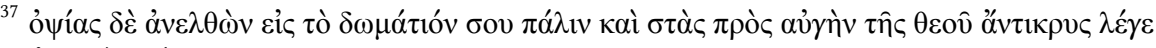

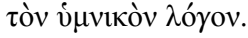


rytuale wykorzystane zostają więc zaklęcia zarówno do Heliosa, jak i do Selene. Po recytacji formuły do bogini należy złożyć ofiarę z mirry i rozpalić ogień, by otrzymać znak w postaci zstępującej na dach gwiazdy. Wtedy osoba wy-

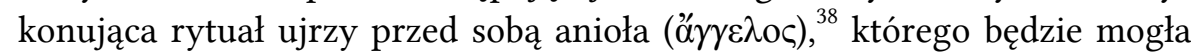
zakląć, by wypełniał prawie wszystkie rodzaje poleceń i zdradzał przyszłość.

\subsection{Helios i kraina zmarłych}

PGM IV 296-466 to defixio, na którą składa się skomplikowany rytuał mający przynieść pożądanie wybranej kobiety. Część instrukcyjna opisuje tworzenie figurek Aresa i kobiety oraz grzebanie ołowianej tabliczki z zaklęciem. Podane są również formuly do wypowiedzenia. Warto odnotować, że formularz tego czaru został zastosowany też w niektórych ołowianych defixiones. ${ }^{39}$ Niezależne potwierdzenia to rzadki przypadek, a ten konkretny zasługuje na tym większą uwagę, że znalezione zostały zarówno tekst zaklęcia, jak i figurka kobiety. Niestety, chociaż odpowiadają one opisowi z PGM, nie mówią one nic o tym, czy czas wykonania rytuału również zgadza się $\mathrm{z}$ omawianym passusem.

Instrukcja mówi o uprzednio zapisanej tabliczce: „Umieść ją, gdy Słońce

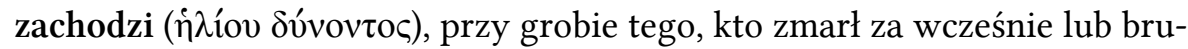
talną śmiercią, kładąc obok również kwiaty sezonowe" ${ }^{\text {"40 }}$ (wersy 333-334). Zaklęcie zapisane na tabliczce zwraca się o przyciągnięcie upragnionej kobiety do bóstw chtonicznych oraz do demonów, w tym demona osoby, przy grobie której umieszczona zostaje tabliczka. Zapisaną na niej długą formułę należy również wyrecytować. Nie jest ona jednak jedynym zaklęciem do wypowiedzenia podczas rytuału.

Ostatnia partia tekstu tego papirusu jest modlitwą do Heliosa, którą należy wypowiedzieć o zachodzie przy grobie. Najpierw następuje odniesienie do boga, jako rządzącego niebem, ziemią, Chaosem i Hadesem, a następnie pada

\footnotetext{
${ }^{38} \mathrm{~W}$ tekście pojawiają się też odniesienia do tej samej postaci, nazywające ją bogiem.

${ }^{39}$ Patrz np: J. Gager, Curse Tablets and Binding Spells, New York - Oxford 1992, s. 97.

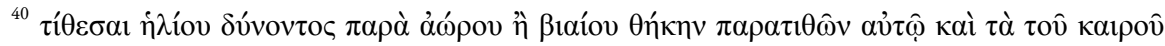
ơv $\theta \eta$.
} 
prośba dotycząca podróży Heliosa przez podziemia oraz jego wpływu na demony (wersy 445-460):

Do głębi ziemi,

do krainy zmarłych ześlij tego demona,

którego szczątki ciała trzymam w swoich rękach,

do niej, NN, w godzinach północnych,

by ruszył w nocy do rozkazów pod twoją mocą,

tak by wszystko, co chcę w głębi mego serca, on mógł

dla mnie sprawić $(\ldots)^{41}$

Ustęp odnosi się do nocnego przemierzania przez Heliosa krainy umarłych, podróży analogicznej do jego jazdy po niebie nad światem żywych w ciągu dnia. Nie jest ważny sposób, w jaki Helios odbywa swoją podróż, ale jej cel. Zaklęcie wypowiedziane o zachodzie Słońca ma uprosić Heliosa, by ten podczas swojej nocnej podróży nawiązał w świecie podziemnym kontakt $\mathrm{z}$ jednym $\mathrm{z}$ demonów, a następnie wysłał go na ziemię, by ten wykonał wolę maga.

W wielu rytuałach mag zwraca się do demonów bezpośrednio, zazwyczaj właśnie stojąc nad grobem. ${ }^{42}$ Nakłania i zaklina demony i duchy zmarlych, by wykonały określone działanie, do którego ich potrzebuje. ${ }^{43} \mathrm{~W}$ omawianym passusie mag nie zwraca się do demonów sam, lecz odwołuje się do boga. Wygląda to jak odwrócenie konwencji: często to duch zmarłego przekazywał treść prośby lub klątwy demonom lub bogom, którzy mieli się zająć jej realizacją. W tym wypadku to sam bóg jest pośrednikiem niosącym treść do demonów i duchów. Mag zwraca się do niego o zachodzie Słońca, czyli tuż przed początkiem jego wędrówki po krainie zmarłych. Pora wypowiadania zaklęcia do Heliosa wydaje się logicznie dobrana: demon przybywający z podziemi ma działać w nocy - trudno jednak wyobrazić sobie zwracanie się wtedy z prośbami do bóstwa solarnego. Noc to jedyny czas, kiedy nie można z nim nawiązać wzrokowego kontaktu, lecz jest to pora, w której przebywa on w części świata,

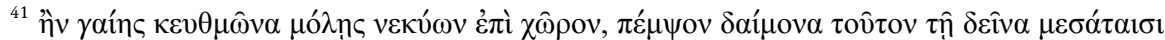

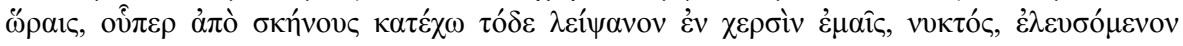

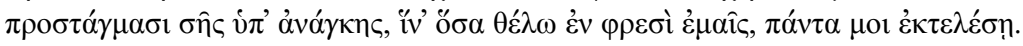

${ }^{42}$ Patrz Johnston, Hekate Soteira (cyt. w przyp. 22), s. 145.

${ }^{43}$ Merkelbach, Totti, Abrasax (cyt. w przyp. 16), s. 11.
} 
do której żywi nie mają dostępu. O zachodzie jednak bóg nie tylko jest świeżo przed swoją drugą wędrówką, może więc wykonać szybko prośbę maga mając ją w pamięci, lecz również - zniżając się za horyzont - zdaje się być fizycznie bardzo blisko człowieka. ${ }^{44}$ Może być to więc odpowiedni moment do zbliżenia się z bogiem - analogicznie do poranka, będącego najważniejszą porą kontaktu $\mathrm{z}$ bóstwem w ciąu dnia. Moment zachodu jest porą, która może być chętnie wybierana na zwracanie się do Heliosa ze względu na nawiązanie do jego podziemnej wędrówki. Potwierdzają to dwa inne ustępy $P G M$, zwracające się do boga z niemal tą samą prośbą co tekst analizowany wyżej.

PGM IV 1928-2005 to $\dot{\alpha} \gamma \omega \gamma \eta^{45}$ - czar, mający przymusić do miłości. Nie wymaga on pojawienia się na grobie zmarłego, wykorzystuje jednak rekwizyt nawiązujący do świata zmarłych, tj. miseczkę z czaszki. Ten rytuał wymaga wypowiedzenia odpowiednich formuł zarówno o wschodzie, jak i zachodzie. Mimo że już o wschodzie Słońca w zaklęciu znajduje się prośba o uzyskanie przez maga kontroli nad demonem, wydaje się mało prawdopodobne, by była to jedna ze zwyczajnych pór, w których odwoływano się do sił chtonicznych. Niewykluczone, że autor tekstu w tym wypadku korzystał z koncepcji zwracania się do Heliosa zarówno o poranku, jak i wieczorem. Być może też dodatkowy zwrot do boga o wschodzie miał już od rana zapewnić nawiązanie dobrego kontaktu z bóstwem. Skutkiem tego miała być większa skuteczność głównego zaklęcia wypowiadanego później.

Modlitwa wypowiadana według PGM IV 1928-2005 już o zachodzie zawiera w sobie bardzo podobne sformułowanie co wcześniej omawiany $P G M$ IV 296-466:

Do głębi ziemi,

Krainy zmarłych, ześlij tego demona,

By ruszył w godzinach północnych z konieczności twoich Rozkazów (...). ${ }^{46}$

\footnotetext{
${ }^{44}$ Cohn, „P. Mich 3404” (cyt. w przyp. 14), s. 248.

${ }^{45}$ Dokładną definicję tego oraz innych rodzajów magii miłosnej można znaleźć w: FARAONE, Ancient Greek Love Magic (cyt. w przyp. 12), s. 24-28.

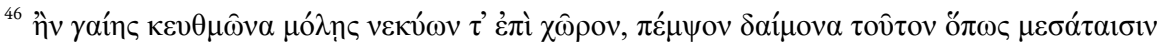

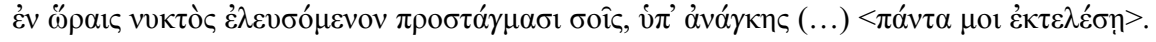


Na podstawie tego znajdującego się między wersami PGM IV 1960-1970 ustępu wydaje się, że omawiane tu zaklęcia do Heliosa mają wspólne źródło w jednym hymnie. Niewykluczone, choć raczej mniej prawdopodobne, że kopista, widząc dwa podobne w formie i przeznaczeniu teksty, postanowił specjalnie upodobnić je do siebie. Tym bardziej, że również w PGM VII 64110, opisującym tym razem nie rytuał miłosny, lecz obrzęd mający wywołać przepowiednię we śnie, odnaleźć można - krótszy tym razem - tekst posługujący się podobnymi sformułowaniami.

W PGM znajdują się rytuały, w których poza zwrotami do bóstw chtonicznych wykorzystywane są modlitwy do Heliosa (np. PGM III 1-164, w którym również zwrot do bóstwa chtonicznego recytowany jest o wschodzie).

\subsection{Inne odniesienia do pór dnia}

Bazując na analizowanych powyżej $P G M$ nie można przyznać racji uwadze Headlama, jakoby do bóstw niebiańskich zwracano się przed nadejściem południa, po przekroczeniu zaś przez Słońce zenitu - do bóstw chtonicznych. ${ }^{47}$ Można próbować potraktować wypowiadane o zachodzie zaklęcia, odnoszące się do podziemnej podróży Heliosa, jako zwroty do boga w pewnej mierze bardziej chtonicznego niż niebiańskiego. Jednak same przykłady PDM XIV 675-694 (PGM XIVc. 15-27) oraz PGM VII 505-528, które zalecają wypowiadanie zaklęć do tego samego boga w tej samej intencji zarówno rano, jak i wieczorem, potwierdzają, że założenie Headlama, bazujące na analizie tekstów literackich, było zbyt uproszczone.

Jedną $\mathrm{z}$ wyróżniających się $\mathrm{w}$ papirusach magicznych pór dnia jest moment poprzedzający sen. Tylko w niektórych przypadkach autor pisał, że chodzi o godziny wieczorne (np. PGM VII 359-369), lub kazał jakąś czynność wykonać w kierunku Księżyca (PDM Suppl. 130-138). Często jednak jedynym odniesieniem do pory rytuału jest zalecenie, by odprawić go przed pójściem do łóżka lub przed snem. Czasami przy określeniach tego typu występuje

${ }^{47}$ W. Headlam, „Ghost-raising, magic, and the underworld I”, Classical Review 16.1 (1902), s. $52-61$, na s. 52 . 
zjawisko analogiczne do opisywanego wyżej porannego milczenia. Stosunkowo liczne wzmianki zabraniają odzywania się do kogokolwiek pomiędzy wykonaniem rytuału a zaśnięciem (PGM V 447-458, VII 619-627, VII 740-755, XXIIb. 32-35; PDM xiv 93-114, xiv 117-149). Takie zalecenie może mieć bardzo praktyczny wymiar: ma prawdopodobnie zapobiec ewentualnemu utraceniu nabytego podczas rytuału lub modlitwy kontaktu z bóstwem. Jego uprzedniemu nawiązaniu zaś sprzyjałby stan czystości, również wymagany przez niektóre instrukcje.

Odpowiednia relacja $\mathrm{z}$ bogiem jest bardzo ważna w niemal wszystkich rytuałach odprawianych „przed snem”. Stanowią one wśród PGM zaskakująco zamkniętą grupę. Większość z tych rytuałów ma doprowadzić do otrzymania wyroczni podczas snu albo do (niekoniecznie nocnego, jako że spać można o różnej porze) spotkania z bóstwem, które samo opowie o wszystkim, co mag chciałby wiedzieć. Sny, na różne sposoby, odgrywały $\mathrm{w}$ antyku ważną rolę w sztuce dywinacji. ${ }^{48}$ Należy jednak pamiętać, że ich rola jest bardzo złożona: w papirusach magicznych najczęściej mamy do czynienia ze specjalnie wywołanymi snami wieszczymi, ale w świecie antycznym popularne było również używanie senników i inkubacja.

Rytuały prowadzące do rozmowy z bogiem nie odbywają się wyłącznie w nocy - w $P G M$ jest wiele takich obrzędów, które można odprawiać w ciągu dnia. Jednak w grupie rytuałów, o których mówi się, że mają być odprawione przed pójściem spać, zdecydowana większość dotyczy wyroczni i kontaktu z bogiem. W niektórych sytuacjach rytuały te mają przynieść dobrą pamięć (np. PGM II 1-64). Ona też pośrednio ma jednak związek z wyroczniami sennymi - jedną z trosk maga było w końcu to, by dobrze zapamiętać co dokładnie przekazał mu bóg.

Treść papirusów wskazuje porę wieczorną nie tylko poprzez zachód Słońca, ale również odnosząc się do konkretnej godziny czy wzejścia Księżyca na niebo (np. w PGM IV 3125-3171). Odniesienia do pory bywają też bardzo ogólne: w niektórych tekstach wskazane jest tylko, czy dany rytuał należy odprawiać w dzień, czy w nocy. Do praktyk stosowanych po zachodzie Słońca należą czynności różnego rodzaju: można wśród nich znaleźć zsyłanie snów (PGM XII 1-13), rytuały miłosne (PGM IV 1716-1870) czy też pojawienie

\footnotetext{
${ }^{48}$ Brashear, „The Greek Magical Papyri” (cyt. w przyp. 2), s. 3395.
} 
się bóstwa (PGM IV 3086-3124). W środku nocy można - wykorzystując do

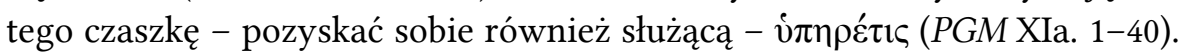
O dziewiątej godzinie nocy należy wypełniać też jeden z elementów rytuału konsekrującego pierścień (PGM XII 270-350).

Zdecydowanie więcej odniesień do konkretnych godzin jest w stosunku do dnia niż do nocy. Trzeba oczywiście pamiętać, że godziny te nie odpowiadają naszym - dzień miał dwanaście godzin licząc od wschodu Słońca, a noc tyle samo, tylko że licząc od zachodu. Starożytna godzina dwunasta dnia wypada więc tuż przed zachodem, a nie w południe, jak według współczesnego mierzenia czasu. W PGM można natrafić na odniesienie do prawie każdej godziny - ewentualny brak którejś z nich w tekście zachowanych papirusów magicznych nie świadczy jednak, że nie była ona wykorzystywana. Dana godzina czasem jest jedyną wskazaną porą rytuału, częściej jednak jest tylko jedną z wielu: np. PGM III 282-409 poza odniesieniami do wschodu Słońca i wzejścia Księżyca odnosi się do godziny trzeciej, dziesiątej i dziewiątej. Ma to prawdopodobnie ułatwiać zorganizowanie w czasie wszystkich elementów rytuału i zachować odpowiednie proporcje między nimi. W kilku tekstach pojawia się odniesienie do „godziny piątej” (œ̋ $\alpha$ \&, np. PGM IV 1-25, VII 846-861). Można próbować rozumieć to odniesienie symbolicznie, nie da się jednak wykluczyć, że godzina ta jest po prostu innym wskazaniem na okolice południa. Sugerować to mogłoby odniesienie jednocześnie do południa i godziny piątej w PGM IV 154-285. Samo południe również pojawia się w instrukcjach papirusów: czy to w towarzystwie innych pór dnia (zaklęcie wypowiadane o wschodzie, w południe i w nocy, $P D M$ lxi 30-41) czy też jako pora oddzielna (PDM xiv 978-980).

W PGM znajdują się też inne formy odniesienia do podziału dnia i nocy na godziny. W jednym z zaklęć o nawiązanie relacji z Heliosem (PGM III 494611) wyliczone zostały symbole boga i jego dwanaście zmieniających się co godzinę form. ${ }^{49}$ Selene wprawdzie nie zmienia swoich form w ciągu nocy, może jednak wysyłać dwunastu aniołów, mających kontrolę nad poszczególnymi godzinami (PGM VII 862-918). Przekonanie o tym, że każda godzina, dzień, a nawet tydzień mają bóstwa lub demony, które sprawują nad nimi kontrolę, jest w PGM łatwo zauważalne.

\footnotetext{
${ }^{49}$ Podobne wyliczenie: PGM IV 1596-1715.
} 
PGM XIII w różnych miejscach zawiera odniesienia do tego, by przed wtajemniczeniem zaprezentować się przed bogami odpowiednich godzin i dni - by zrobić to w odpowiedni sposób autor odsyła do innego dzieła, w którym mają być zapisane ich imiona. W treści samego PGM XIII (wersy 215-225 i 720-734) znajdują się odpowiednie wykresy mające pomóc określić, jaki bóg rządzi danej nocy sferami nieba. Inny papirus, PGM II 1-64, zawierający prośbę o nocną przepowiednię, odnosi się do Apolla jako boga kontrolującego daną noc oraz godzinę modlitwy (wersy 5-10). Zazwyczaj jednak nie dostajemy w PGM tak konkretnych informacji. W większości odniesienia do bóstw rządzących daną jednostką czasu są bardzo ogólne dowiadujemy się z nich w zasadzie tylko, że tacy bogowie istnieją. Nie można przez to porównać wzmianek o nich $\mathrm{z}$ instrukcjami odprawiania rytuałów o konkretnych godzinach - acz nie byłoby niczym zaskakującym, gdyby w niektórych z tych przypadków to wzgląd na odpowiedniego boga sugerował godzinę działań magicznych.

\section{KSIĘŻYC I KALENDARZ}

Nie tylko odniesienia do pór dnia są w papirusach magicznych bardzo zróżnicowane. Nie tak liczne, ale również istotne, jest w nich określanie czasu rytuału za pomocą faz Księżyca, jego stosunku do znaków zodiaku, Słońca i planet. Niejednokrotnie występują też odwołania do konkretnych dni miesiąca lunarnego.

\subsection{Pełnia}

W PGM bezpośrednie odniesienia do faz Księżyca nie są częstym określeniem czasu. Razem ze wskazaniami konkretnych dni miesiąca lunarnego tworzą już jednak sporą grupę, której zdecydowanie nie można pominąć $\mathrm{w}$ analizie pór rytuałów. Pełnia w pewnym sensie towarzyszy rytuałom, które można podzielić na trzy grupy: miłosne, wróżenie/spotkanie z bogiem w celu otrzymania wyroczni, zsyłanie snów. Jedno z odnoszących się do pełni zaklęć nie ma określonego w tekście przeznaczenia (PGM LVIII 15-39). 
PDM xiv 376-394 opisuje, w jaki sposób za pomocą wpuszczenia myszy do pomieszczenia, w którym kąpie się kobieta, można zdobyć zainteresowanie swojej wybranki. Należy to zrobić podczas pełni Księżyca, co zgadza się z niektórymi występującymi w literaturze przekonaniami łączącymi ze sobą pełnię i miłość. ${ }^{50}$

Ogół $P G M$ wskazuje bardziej na pierwszą część miesiąca niż na samą pełnię jako odpowiednią do zaklęć miłosnych. PDM xiv 772-804 zaleca podać kobiecie napój miłosny czternastego dnia - tuż przed pełnią. Na trzynasty i czternasty dzień miesiąca jako czas odpowiedni na ofiarę dla Selene i towarzyszące jej zaklęcie miłosne wskazuje również PGM IV 2708-2784. Oddalając się coraz bardziej od pełni, ale pozostając przy zaklęciach miłosnych pierwszej połowy miesiąca, należy odnieść się również do PDM xiv 335-355 (siedem pierwszych dni miesiąca) oraz PDM xiv 636-669 (trzeci dzień miesiąca).

Nie można jednak powiedzieć, aby wyrocznie oraz spotkania z bogiem odbywały się wyłącznie podczas pełni. Wyrocznia udzielana przez Sarapisa według PGM V 1-53 zaleca wręcz, by rytuał właśnie nie wypadł w czasie pełni. Autor papirusu odwołuje się jednak też do innego manuskryptu i przyznaje, że zalecenie z niego wręcz wymaga obecności pełnego Księżyca. Spotkanie z Heliosem odbywać ma się drugiego lub - lepiej - czwartego dnia miesiąca (PGM VI 1-47). Podczas pełni wypadającej przed nim należy jednak wypowiedzieć odpowiednie formuły. Wróżenie z użyciem naczynia z PDM xiv 695-700 przypada zaś na piętnasty dnia miesiąca, co jest dniem wypadającym przy pełni.

O spotkaniu z bogiem, które ma się odbywać podczas pełni, mówi PGM IV 475-829. Przygotowania do niego powinny się jednak odbywać w czasie nowiu. Spotkanie nie ma charakteru wyroczni, lecz pewnego rodzaju mistycznego doznania. Po wszystkich przygotowaniach i oczyszczeniu, które miały odbyć się w okolicy nowiu w znaku Lwa, można było spotykać się $\mathrm{z}$ bogiem trzy razy w ciągu roku. Według autora tekstu sam bóg nakazał jednak, by korzystać ze spotkania raz w miesiącu, w czasie pełni. Według Hansa Betza ta uwaga jest śladem zmiany z kierowania się kalendarzem sezonowym na astrologiczny. ${ }^{51}$

${ }^{50}$ J. M. BREMER, „Full moon and marriage in Apollonius' Argonautica”, Classical Quarterly 37.2 (1987), s. 423-425.

${ }^{51}$ H. D. BEtz, The Mithras Liturgy. Text, Translation, and Commentary, Tübingen 2003, s. 220. 
Do grupy zsyłającej sny należą dwa rytuały (PDM Suppl. 60-101 i Suppl. 101-116). Zawierają one $\mathrm{w}$ treści swoich zaklęć odniesienia do świata podziemnego. W pierwszym przypadku przygotowanie do rytuału zaczyna się już pierwszego dnia miesiąca. Główna jego część odbywa się jednak piętnastego dnia. W treści wypowiadanego wtedy zaklęcia znajdują się odniesienia do ciała w podziemiach, do duszy w niebie oraz do Ozyrysa.

Drugi z omawianych rytuałów nie wymaga dłuższego przygotowania. Wypowiadane w połowie miesiąca zaklęcie sprowadzające na kogoś sen, który ma skłonić do wykonania konkretnych czynności, również nawiązuje do świata podziemnego oraz kojarzonych z nim bóstw: Ozyrysa i Anubisa. Obydwa rytuały są wykonywane w bezpośredniej bliskości pełni, ale treść papirusów nie odnosi się do niej bezpośrednio. Pierwszy na główny moment rytuału wskazuje piętnasty dzień miesiąca, drugi - połowę miesiąca. Równie dobrze ten czas, jako okres graniczny, może odnosić się nie do pełni jako takiej, ale do wzrastania Księżyca (jako jego ostatni dzień) lub ubywania Księżyca (jako jego początek).

Tę wątpliwość, do czego właściwie odnosi się wskazówka autora, rozwiać może inne zaklęcie zsyłające sen, znajdujące się bezpośrednio za analizowanymi dwoma: PDM Suppl. 117-130. W celu wywołania snu wysyła ono, dzięki mocy Anubisa, ducha osoby zmarłej. Mag zabrania duchowi wstąpić danej nocy do nieba, by mógł spełnić powierzone sobie zadanie - jest to zaś noc z 25. na 26. dzień miesiąca, a więc występująca podczas ubywania Księżyca. Wygląda więc na to, że czas w środku miesiąca jednocześnie może być kojarzony z pełnią, jak i odnosić się do początku okresu ubywania Księżyca.

\subsection{Księżyc ubywający}

Odniesienia do ubywającego Księżyca najczęściej pojawiają się wprost, a nie poprzez wskazanie odpowiednich dni miesiąca. W tym czasie odbywają się opisane w $P G M$ rytuały różnego rodzaju - między innymi obrzędy związane z pierścieniem. PGM V 304-369 informuje, że zakopanie pierścienia $\mathrm{w}$ grobie $\mathrm{w}$ ramach rytuału mającego podporządkować kogoś magowi daje lepszy efekt, gdy Księżyc ubywa. Jest to zrozumiałe, skoro dni pod ko- 
niec miesiąca, kiedy Księżyc staje się niewidoczny, były uważane za czas, w którym duchy mogły krążyć swobodnie. ${ }^{52}$

Również $\mathrm{w}$ drugiej połowie miesiąca należy zacząć przygotowania do konsekracji pierścienia mającego przynieść sukces i uznanie. PGMXII 376396 wskazuje z kolei na czas ubywania Księżyca jako na odpowiedni do rzucenia uroku powodującego bezsenność, mogącego nawet spowodować śmierć. Jest to kolejny z rytuałów o złowieszczym przeznaczeniu wykonywanych w drugiej połowie miesiąca.

\subsection{Nów}

Bardzo rozbudowanym rytuałem, w którym ważne miejsce zajmują odniesienie do nowiu, jest ten zawarty w PGM XIII, znanym też pod nazwą

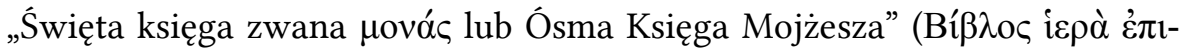

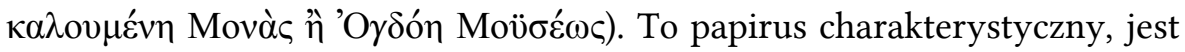
bowiem powstałą w połowie IV w. n.e. kompilacją trzech różnych zachowanych wersji tego samego rytuału. ${ }^{53}$ Były one prawdopodobnie przekazywane oddzielnymi drogami przez różnych magów, przechodząc przy tym różne zmiany, m.in. polegające na dopisywaniu dodatków z innych tekstów apokryficznych przypisywanych Mojżeszowi. ${ }^{54}$

Pierwsza wersja rytuału (PGM XIII 1-343) opisując przygotowania do niego zaleca zachowanie czystości rytualnej przez czterdzieści jeden dni, dbając o to, by ostatni z nich przypadł na dzień, w którym Księżyc w nowiu będzie znajdował się w znaku Barana (wersy 1-10). Dopiero po tym okresie można przystąpić do głównego rytuału inicjacji; wcześniej jednak, na dwadzieścia jeden dni przed nim należy zebrać odpowiednie kwiaty, które będą użyte w jego trakcie (wersy 23-28). W ramach przygotowania do rytuału należy podczas

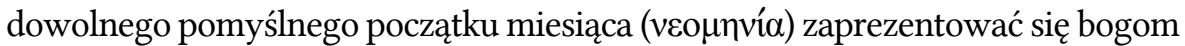
kontrolującym godziny dnia (wersy 30-32). Druga wersja tego samego rytuału,

\footnotetext{
${ }^{52}$ A. T. Grafton, N. M. Swerdlow, "Calendar dates and ominous days in ancient historiography", Journal of the Warburg and Courtauld Institutes, 51 (1988), s. 14-42, na s. 16.

${ }^{53}$ Graf, „Magic” (cyt. w przyp. 7), s. 7.

${ }^{54}$ Ibidem, s. 8.
} 
znajdująca się w PGM XIII 343-646, również instruuje, by zachować czystość przez 41 dni przed nowiem wypadającym w znaku Barana. Wprowadza jednak dodatkowy element: gdy Księżyc wejdzie w odpowiedni znak, ostatnią noc przed końcem oczyszczenia należy spędzić, śpiąc na podłodze (wersy 345-352). Również w tej wersji występuje nawiązanie do dwudziestego pierwszego dnia: tu zalecenie dotyczy jednak palenia kadzidła po dwudziestym pierwszym dniu.

Trzecia wersja rytuału, opisująca przygotowanie do niego w PGM XIII 646-734, też wspomina o czystości: wygląda jednak na to, że tu ma ona trwać przez siedem ostatnich dni ubywającego przed nowiem Księżyca, tak by po jego zakończeniu - podczas nowiu - spać na ziemi. Ta część papirusu nie nawiązuje już do liczby 21, wprowadza jednak nieznany poprzednim tekstom element: instruuje, by zapoznawać się z imionami bogów kontrolujących godziny i tygodnie przez siedem dni, wstając o świcie i witając przez ten tydzień Heliosa (wersy 671-676).

Instrukcja wyjątkowo podkreśla, by dni oczyszczenia kończyły się podczas nowiu, gdy Księżyc wchodzi w znak Barana. Można doszukiwać się dodatkowej symboliki związanej z inicjacją: wtajemniczany, wchodząc w posiadanie nowej wiedzy o boskich sprawach, w pewnym sensie rozpoczyna nową część życia. Nów rozpoczyna nowy miesiąc, Baran jest zaś pierwszym znakiem zodiaku. Cała otoczka czasu towarzyszącego rytuałowi kojarzy się więc z nowym początkiem.

PGM XIII to jedyny przykład, na którym tak wyraźnie można porównać tego typu różnice $\mathrm{w}$ odnoszących się do tego samego rytuału tekstach wychodzących z jednego źródła. W pewien sposób zmiany dokonane w instrukcjach z „Ósmej Księgi Mojżesza” potwierdzają, że odpowiedni czas danych czynności był ważny w każdej z tradycji przekazywania tego tekstu. Niektóre pory zostały zachowane we wszystkich wersjach (nów Księżyca był za każdym razem ważnym momentem w przygotowaniu do rytuału), inne zaś dodano. Te uzupełnienia są ważne, wskazują bowiem, że czas obrzędu nie stał się obojętny, a jedynie zmieniony lub odniesiony do innych aspektów. Magowie nie uważali, że wprowadzając zmiany zniekształcają znaczenie tekstu - modyfikowanie widzieli jako podkreślanie tego, co naprawdę ważne, lub przystosowywanie rytuału do lepszego wypełniania swojego zadania. ${ }^{55}$

\footnotetext{
${ }^{55}$ S. I. Johnston, „Sacrifice in the Greek Magical Papyri”, [w:] Magic and Ritual in the Ancient World, P. Mirecki, M. MeYer (red.), Leiden 2002, s. 344-358, na s. 347.
} 
Innym jeszcze przykładem odniesienia do nowiu jest wskazanie go jako czasu odpowiedniego na utworzenie figurki mającej przynosić pomyślność dowolnemu miejscu, w którym będzie ustawiona - na przykład sklepowi (PGM IV 2373-2440). Jest to kolejny przypadek, w którym odniesienie do nowiu można odczytywać raczej nie w ramach chwilowej nieobecności Księżyca na niebie, a jako nawiązanie do rozpoczynającego się okresu ponownego wzrostu Księżyca - a w tym wypadku wzrostu również pomyślności i zysków.

\subsection{Wzrastający Księżyc}

Ze wszystkich części miesiąca najczęściej jako pora odpowiednia do uprawiania magii jest wskazana pierwsza jego połowa - zazwyczaj poprzez wskazanie konkretnych dni miesiąca. Często w instrukcjach pojawia się pierwszy dzień miesiąca, równoważny w zasadzie z nowiem. I tak pierwszego dnia miesiąca można wypowiedzieć zaklęcie na dobrą pamięć (PGM III 410423) albo uleczyć epilepsję (PGM XCV). Wtedy można rozpoczynać też procedury na przewidywanie przyszłości oraz wzmocnienie (PGM III 424-466). Sam początek miesiąca to też dobry okres na zaklęcia z użytkiem naczynia (PGM LXI 30-41). Również wtedy, w nocy, może mieć miejsce objawienie Apolla (PGM II 1-64).

Drugi (PGM VI 1-47), czwarty (PGM VI 1-47) i szósty (PGM III 479-483) dzień miesiąca jest dobry na przewidywanie przyszłości po zwróceniu się do Heliosa. Najwięcej jednak można najwidoczniej zrobić trzeciego dnia miesiąca, do którego odniesień jest najwięcej. To właśnie wtedy odbyć się ma opisywany wcześniej rytuał wtajemniczenia (PGM IV 26-51). Trzeciego można stworzyć filakterium (PGM IV 3125-3171) oraz rzucić zaklęcie przymuszające ( $P G M$ IV 2622-2707). Trzeci dzień miesiąca jest też dobrą porą na dywinację i wyrocznie - zarówno poprzez wróżenie z użyciem naczynia (PGM IV 154-285), jak też bezpośrednią wizję lub spotkanie z bogiem (PGM III 633-731). Nie dziwi to, jeśli się weźmie pod uwagę, że trójka jest jedną $\mathrm{z}$ liczb niosących ze sobą wyjątkowo duże przesłanie symboliczne ${ }^{56}$ a papi-

\footnotetext{
${ }^{56}$ Np. o znaczeniu trójki w tradycji greckiej patrz: E. B. LEASE, „The number three, mysterious, mystic, magic", Classical Philology 14.1 (1919), s. 56-73.
} 
rusy magiczne mają własną specyfikę liczbową opartą na tradycji egipskiej, a zapewne i semickiej. Nie sposób wskazać konkretnego symbolicznego skojarzenia, które zadecydowało o zaleceniu wykonywania danego obrzędu akurat trzeciego dnia miesiąca - chyba że, kierując się wyłącznie praktycyzmem, zaryzykujemy stwierdzenie, że akurat ten dzień jest ważny, ponieważ dopiero wtedy Księżyc faktycznie jest już dobrze widoczny.

\subsection{Zaćmienie Księżyca}

Wyjątkowym w $P G M$ odniesieniem do zaćmienia jako pory, w której mag może podejmować próby wpływania na Selene, jest passus zawarty w $P G M$ IV 2241-2358. Hymn, nazwany „hymnem do wschodzącego Księżyca”, ma służyć zastraszeniu bogini. Mag ogłasza, że chce utrzymać ciemność; nie uderzy w cymbały, by jej nie odpędzić (wersy 2295-2300). ${ }^{57}$ Zaklęcie ma zmusić boginię do wykonania jakiejś - niewspomnianej w papirusie czynności dla maga.

\subsection{Dni pomyślne i niepomyślne}

Wyjątkowo rzadko odwoływano się również do konkretnych dni tygodnia. Odniesienia takie znajdują się w zasadzie w dwóch tekstach: PGM IV 1-25 oraz PGM XXXVI 320-332. W PGM prawie nie padają konkretne daty. Jedną jest występujący w PGM CI 1-53 jako „dzisiaj” dwudziesty piąty dzień miesiąca Hathyr drugiego roku indykcji.

Odniesień do miesiąca kalendarzowego również jest niewiele. Są obecne np. w PGM XXVIIIa. 1-7, XXVIIIb. 1-9 oraz XXVIIIc. 1-11. W zbiorze PGM

\footnotetext{
${ }^{57}$ Dziękuję za uwagi do tego fragmentu prof. UW. dr. hab. Pawłowi Janiszewskiemu. Zob. też: M. SMITH, „The Hymn to the Moon, PGM IV 2242-2355”, [w:] Proceedings of the Sixteenth International Congress of Papyrology, New York, $24-31$ fuly 1980, R. S. BAGNALL, G. M. BrowNe, A. E. Hanson, L. Koenen (red.) [= American Studies in Papyrology 23 (1981)], Chico 1981, s. 643-654. Smith uważa, że ciemność bierze się z mającego miejsce podczas recytacji hymnu nowiu. Przychylam się jednak do tezy Janiszewskiego, przedstawianej wielokrotnie na jego seminariach, że mamy tu do czynienia z zaćmieniem.
} 
występuje też passus odnoszący się nie do jednego miesiąca kalendarzowego, a do całego egipskiego roku. Znajduje się on na PGM VII 272-283. Jest to fragment identyfikowany jako kalendarz precyzujący dni nieodpowiednie do wykonywania praktyk magicznych. ${ }^{58}$ Jako taki stanowiłby jeden z rzadkich w $P G M$ przykładów zwrócenia uwagi na czas nieodpowiedni do pewnego działania, zamiast na zalecany. Instrukcje do rytuałów odnoszą się czasem do różnych wersji kopiowanego manuskryptu lub opinii dotyczących odprawienia obrzędu. Odnotowują często istnienie kilku (niepokrywających się) pór uznawanych za korzystne dla danych praktyk magicznych, ale rzadko wspominają o tym, by szczególnie wystrzegać się działania w jakimś czasie. Jednym z takich wyjątków jest PGM III 424-466, gdzie jest wskazane, by Księżyc nie był w koniunkcji.

Uznanie, że PGM VII 272-283 wskazuje dni niekorzystne, nie może być traktowane jako pewne. $\mathrm{W}$ jego tekście nie ma odniesienia, które by to potwierdzało. Ponadto kalendarze podobne w wymowie były stosowane w Egipcie do określania dni zarówno odpowiednich, jak i nieodpowiednich do różnych praktyk, np. religijnych (składanie ofiar, czczenie konkretnych bóstw) czy też życia domowego (urządzanie uczt, współżycie). ${ }^{59}$ Tekst PGM VII 272-283 jest jednak w porównaniu z większością z nich niezwykle zwięzły. Składa się on jedynie $\mathrm{z}$ wyliczenia miesięcy i dopisanych do nich dni - w liczbie od trzech do dziewięciu przy każdym miesiącu.

W PGM VII 155-167 występuje kalendarz podobnego typu. Jest to lista trzydziestu dni egipskiego miesiąca księżycowego z wypisanymi obok porami

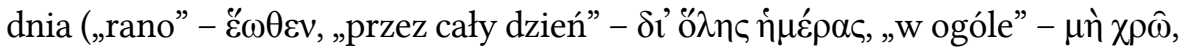
„W południe” - $\mu \varepsilon \sigma \eta \mu \beta \rho i ́ \alpha \varsigma$, ,po południu/wieczorem” - $\delta \varepsilon i ́ \lambda \eta \varsigma)$. Wskazuje ona - zgodnie ze swoim tytułem - dni i godziny odpowiedne dla wróżbiarstwa. ${ }^{60}$ Prawdopodobnie lista ta służyła jako instrukcja pomocnicza dla wróżbity.

Trudno wskazać wyraźną zależność pomiędzy częścią miesiąca i fazą Księżyca a odpowiednią porą na dywinację według omawianego kalendarza, ale

${ }^{58}$ F. NAETher, M. Ross, „Interlude: A series containing a hemerology with lengths of daylight”, Egitto e Vicino Oriente 31 (2008), s. 59-90, na s. 69.

59 T. A. BÁcs, „Two calendars of lucky and unlucky days”, Studien zur Altägyptischen Kultur 17 (1990), s. 41-64, na s. 50

${ }^{60}$ NAETher, Ross, „Interlude” (cyt. w przyp. 58), s. 68. 
można poczynić pewne obserwacje. Zarówno w pierwszej, jak i drugiej połowie miesiąca znajdują się dni, w których nie można wróżyć w ogóle. W pierwszej połowie są to dni oznaczone trójką lub jej wielokrotnością (czyli: trzeci, szósty i dziewiąty dzień miesiąca). $W$ drugiej połowie miesiąca są to m.in. dwa dni występujące bezpośrednio po pełni (szesnasty i siedemnasty). Dni, w których można wróżyć przez cały dzień, występują częściej w pierwszej (pięć razy) niż w drugiej połowie (trzy razy). Im bliżej pełni lub nowiu, tym tych dni jest więcej.

$\mathrm{Z}$ papirusami tego typu kojarzą się też instrukcje wymieniające cały zestaw dni odpowiednich do danego rytuału - jak PGM V 213-303. Teksty takie potwierdzają, że kwestia czasu w rytuałach była na tyle istotna, by nie tylko wspominać o niej w pojedynczych instrukcjach do konkretnych działań i zaklęć, ale też by tworzyć całe rozpiski tego, kiedy można zajmować się magią. Dają nam tym samym świadectwo bardziej wskazujące na powszechność zainteresowania tym tematem wśród magów i wróżbitów niż pojedyncze wzmianki o przeznaczeniu któregoś z kolei dnia miesiąca na dany rytuał lub wpływie fazy Księżyca na zaklęcie.

\subsection{Określenia astrologiczne}

W wielu tekstach zawartych w PGM Księżyc warunkuje odpowiedni czas rytuału nie tylko poprzez fazę, w jakiej się znajduje. Wpływy astrologii doprowadzily do tego, że oczekiwano, iż odpowiedni czas na przeprowadzanie konkretnych praktyk magicznych może być wskazany poprzez ustalenie, w jakim znaku zodiaku jest obecny Księżyc lub też w jakim jest on stosunku do planet i Słońca.

Pomimo że działanie planet może zależeć od znaku zodiaku i ustawienia, w którym się znajdują, każda z nich ma też odgórnie przypisany do siebie jakiś wpływ. I tak Jowisz, Wenus i Księżyc były uważane za planety o pozytywnym wpływie. Saturn i Mars miały być szkodliwe, Słońce i Merkury uważano za mieszane: mogły mieć zarówno dobry, jak i zły wpływ. ${ }^{61}$ Zgadza się to z treścią PGM XIII 734-1077, który (wersy 1027-1038) zaleca przygotowanie odpowiednich rzeczy do rytuału, podczas gdy Księżyc

${ }^{61}$ Ibidem, s. 96. 
jest na wschodzie i w koniunkcji z dobroczynną planetą, Zeusem lub Afrodytą [tj. Jowiszem lub Wenus - JC], i gdy żadna szkodliwa, Kronos albo Ares [Saturn i Mars - JC] nie jest w aspekcie. Najlepiej zrób to, gdy jedna z trzech życzliwych planet jest w swoim własnym domu, podczas gdy Księżyc zajmuje pozycję w koniunkcji albo w aspekcie albo w opozycji diametralnej i kiedy planeta również jest na wschodzie, gdyż wtedy rytuał będzie efektywny. ${ }^{62}$

Passus ten jest jednym z najbardziej szczegółowych wskazań astrologicznych co do czasu wykonywania danej procedury w PGM. Poza tym tekstem jeden tylko wymaga obecności Księżyca w koniunkcji z planetami pomyślnymi lub znajdującymi się $\mathrm{w}$ dobrych domach (PGM V 1-53). Nieliczne też odnoszą się do specjalnego ustawienia Księżyca i Słońca względem siebie (wspomniany już PDM xiv 1003-1014 tudzież PGM IV 2145-2240).

Najczęściej czas ma być określony wyłącznie na podstawie obecności Księżyca w danym znaku zodiaku, czasem jednak Księżyc musi być też w odpowiedniej fazie. Opisywane już częściowo ustępy PGM XIII zakładały na przykład, by zakończenie oczyszczenia przed podjęciem się rytuału miało miejsce podczas nowiu wypadającego w znaku Barana. PGM VII 300a-310 zakłada, że rzucenie konkretnego uroku miłosnego powinno mieć miejsce, podczas gdy przybywający Księżyc znajduje się w Baranie lub Byku.

Odniesienia astrologiczne w magii nie były wyłącznie częścią instrukcji do konkretnych rytuałów i praktyk. W skład $P G M$ wchodzą dwa horoskopy astrologiczne niezwiązane raczej z magią. Pierwszy z nich (PGM IV 835-849) jest opisem wpływu poszczególnych planet na poszczególne fazy życia (uważano bowiem, że w życiu są lata i etapy szczególnie szczęśliwe i niesprzyjające $^{63}$ ). Drugi (PGM XLII 52-75) jest typowym przykładem horoskopu odnajdywanego na egipskich papirusach: zapisem daty urodzenia oraz pozycji planet $\mathrm{w}$ stosunku do zodiaku w tym dniu. Interpretacja horoskopu nie jest zapisana, gdyż prawdopodobnie była udzielana klientom astrologa ustnie. ${ }^{64}$

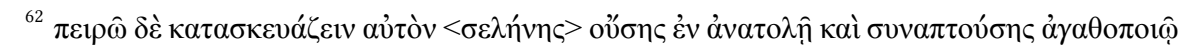

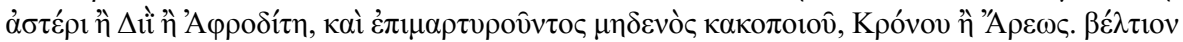

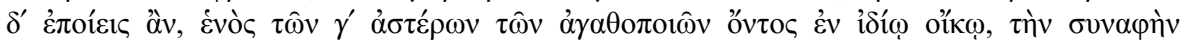

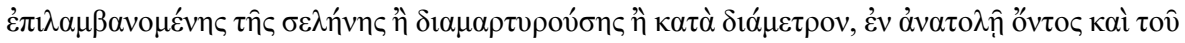

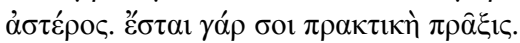

${ }^{63}$ Barton, Ancient Astrology (cyt. w przyp. 33), s. 187-189.

${ }^{64}$ BrasheAr, „The Greek Magical Papyri” (cyt. w przyp. 2), s. 3456. 
Dla tematu czasu ważniejsze są jednak dwa inne horoskopy (PGM III 275281; PGM VII 284-299), które mają wskazywać pory szczególnie korzystne dla uprawiania różnych rodzajów magii. Bazują one na obecności Księżyca w znaku zodiaku. Wyznacza to częstotliwość, z jaką można by według nich odprawiać rytuały magiczne różnego rodzaju pod wyjątkowo dobrym wpływem. Nie jest to jednak duże ograniczenie, Księżyc przechodzi bowiem z jednego znaku zodiaku do drugiego co dwa-trzy dni.

Horoskop z PGM III 275-281 jest niestety niepełny ze względu na lakuny. PGM VII 284-299, zawierający drugi horoskop, jest jednak kompletny. Porównanie obydwu pozwala stwierdzić, że wykaz znaków zodiaku wywierających pozytywny wpływ na dany rodzaj magii nie był czymś ustalonym odgórnie i prawdopodobnie zależał w dużej mierze od przekonań i symboliki zastosowanych przez astrologa/maga.

PGM III 275-281 zakłada następującą zależność: w znaku Panny możliwe jest uzyskanie wszystkiego, co (jak) chcesz, w Raku - pojednanie i dywinacja powietrzna, w Bliźniętach - zaklęcia wiążące, w Wadze - inwokacja (wezwanie), zaklęcie uwolnienia, nekromancja (ze względu na lakuny nie jest pewne, czy część z tego nie należy jednak do innego znaku), w Rybach (lakuna) uroki miłosne, w Strzelcu - interesy, w Koziorożcu (iאavóv) zabezpieczenie/kaucja (lakuna) w (koniec tekstu). ${ }^{65}$

PGM VII 284-299 prezentuje się nieco inaczej: Księżyc w Pannie - do uzyskania jest wszystko, w Wadze - nekromancja, w Skorpionie - wszystko zadające zło, w Strzelcu - inwokacje i zaklęcia do Słońca i Księżyca, w Koziorożcu - „powiedz, cokolwiek chcesz, dla najlepszego rezultatu”, w Wodniku - uroki miłosne, w Rybach - przewidywanie przyszłości, w Baranie dywinacje z ognia, uroki miłosne, w Byku - zaklęcia z użyciem lampy, w Bliźniętach - zaklęcia o zdobywanie łaski i przysług, w Raku - filakteria, w Lwie - pierścienie lub zaklęcia wiążące. ${ }^{66}$

Można stwierdzić, że omawiane horoskopy zgadzają się ze sobą

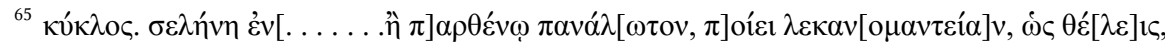

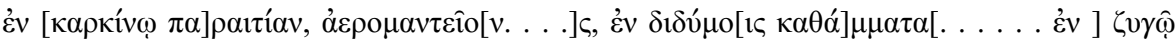

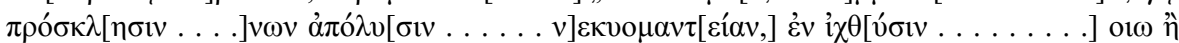

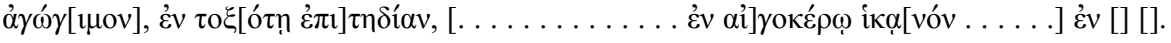

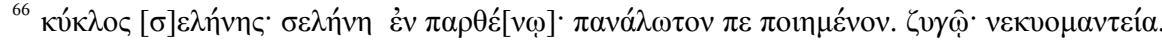

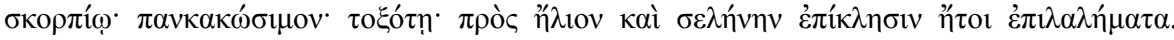


w zasadzie w trzech przypadkach: Waga wydaje się potwierdzona przez obydwa jako znak sprzyjający nekromancji, Panna i Koziorożec są zaś wyjątkowo korzystne i mogą mieć dobry wpływ w zasadzie niemal na wszystkie działania. Między pozostałymi znakami występują jednak spore różnice. Jeśli chodzi o występowanie zgodności między horoskopami a instrukcjami do poszczególnych zaklęć, wydaje się, że występowanie zbieżności między nimi byłoby kwestią wspólnego źródła, poprawek kopisty lub przypadku. Trudno wyjaśniać je tradycjami lokalnymi albo wspólnym czasem powstania ze względu na charakter źródła - możemy wydatować, kiedy papirusy zostały zapisane, ale trudniej wskazać, kiedy powstała treść poszczególnych zaklęć i jak kształtowała się w tradycji ustnej.

Trudno mówić o jednej ścisłej regule rządzącej wpływami astrologii na magię. Przykładowo: urok miłosny znajdujący się, tak jak jeden $\mathrm{z}$ omawianych horoskopów, w PGM VII (wersy 300a-310) zakłada rzucanie go, podczas gdy Księżyc znajduje się w znaku Barana lub Byka, co zgadza się z sugestią z PGM VII 284-299. Z kolei jednak inna (PGM II 64-183) procedura mająca wywołać przepowiednię od Apolla ma być przeprowadzana w znaku Bliźniąt, który w żadnym z omawianych horoskopów nie był przeznaczony do żadnej formy dywinacji.

\section{WNIOSKI KOŃCOWE}

W przypadku zagadnienia czasu i pory odprawiania rytuałów magicznych atrakcyjne wydaje się ujęcie go w ramach statystycznych. Jakkolwiek jest to podejście nieidealne, zwłaszcza na stosunkowo niedużym i zróżnicowanym materiale badawczym, jest pomocne w podsumowaniu pewnych prostych zależności. Zestawienie wszystkich występujących w PGM odniesień do czasu z konieczności będzie jedynie ogólnym zarysem, jest jednak warte przedstawienia. W PGM i PDM występuje około 210 pewnych bezpośrednich odniesień do momentu wykonywania danej czynności. Konieczne jest jednak

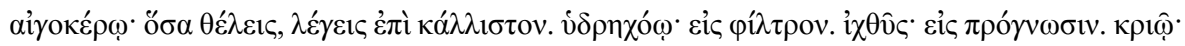

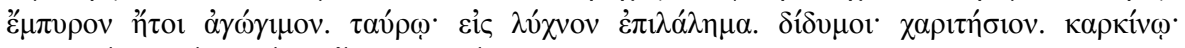

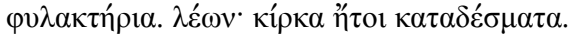


zdanie sobie sprawy z tego, że liczba wyrażeń określających czas działania nie jest równa liczbie czynności, do których się odnosi: np. w opisie jednego rytuału występuje kilka odniesień do tego samego wschodu Słońca. Poza tym są passusy, w których nie można rozstrzygnąć, czy poprzez wschód autor tekstu ma na myśli zwrócenie się w stronę świata, czy porę dnia - zwłaszcza gdy tekst jest niekompletny.

Najczęściej pojawiającą się w papirusach magicznych porą jest wschód Słońca i szerzej pojęty poranek. Odniesienia do niego stanowią blisko trzydzieści procent (ok. pięćdziesiąt dziewięć odniesień), co może mieć związek ze szczególnym kultem Słońca w Egipcie. Jednak już zachód Słońca pojawia się zdecydowanie rzadziej: jest ich około jedenaśnie, drugie tyle zaś stanowią bezpośrednie odniesienia do pory wieczornej. Razem stanowią one dziesięć procent wszystkich odniesień do czasu. Do tej liczby nie zostały jednak wliczone określenia odnoszące się do wieczora jedynie poprzez nawiązanie do momentu bezpośrednio przed położeniem się spać - ta grupa określeń została wyodrębniona ze względu na inne wspólne cechy rytuałów, do których się odnoszą. Około piętnaście procent (trzydzieści odniesień) stanowią wskazania konkretnych dni miesiąca (trzy odnoszą się wprost do konkretnych miesięcy z kalendarza egipskiego, zazwyczaj jednak chodzi ogólnie o miesiąc lunarny). Tu dodać trzeba, że jako jedno odniesienie potraktowane zostały również wyliczenia obejmujące ciągiem kilka dni odpowiednich dla danego rytuału, w tym jedno mówiące o dziewięciu różnych dniach z PGMV 213-303. Nie zaliczyłam do tej kategorii nielicznych passusów w formie wyodrębnionych i nienawiązujących do konkretnego rytuału kalendarzy przedstawiających dni korzystne i niekorzystne dla różnego rodzaju czynności.

Odniesienia do dni miesiąca lunarnego można zestawić z określeniami łączącymi czas działania magicznego $\mathrm{z}$ fazami Księżyca - tych zaś w całym zbiorze jest około piętnaście (siedem procent). Również odnoszą się do Księżyca w określaniu czasu wskazania astronomiczne, kilkukrotnie pokrywające się z odniesieniami do konkretnych faz lub dni. Obejmują one obecność Księżyca w konkretnym znaku zodiaku oraz jego koniunkcje, zwłaszcza ze Słońcem. Tego typu odniesień znaleźć można w PGM około dwadzieścia pięć (jedenaście procent). Pozostałe, niemieszczące się w powyższym podsumowaniu określenia czasu działań magicznych stanowią różnorodną grupę, obejmującą przede wszystkim odniesienia do różnych pór 
dnia (bardzo ogólnych, jak: „w nocy”, „w dzień”, oraz szczegółowych, wskazujących na konkretne godziny). Do tej grupy badawczej dodać należy występujące wśród PGM horoskopy.

W niektórych rytuałach i zaklęciach wskazana pora łączy się poprzez kontakt lub bezpośrednie nawiązanie z konkretnym bogiem. Tego typu powiązań, w których bóstwo i wskazanie pory znajdują się w sytuacji, w której może istnieć między nimi jakaś korelacja, jest nieco ponad siedemdziesiąt. Nie zostały do tej liczby wliczone ustępy papirusów, w których imię bóstwa jest używane wyraźnie przede wszystkim jako zamiennik do nazwy ciała niebieskiego. Spośród tych siedemdziesięciu odniesień do bogów połowę stanowi nawiązanie lub zwrot do bóstwa solarnego pod różnymi nazwami: najczęściej występującą jest Helios, dalej Apollo, Phre i inne. Odniesień tych jest trzydzieści siedem, z czego dwadzieścia sześć pojawia się przy nawiązaniu do wschodu Słońca. Drugą największą grupą bóstw występujących we wspomnianych passusach są boginie lunarne, pojawiające się pod imionami Selene, Hekate, Izyda, Persefona/Kora.

W niektórych papirusach jest więcej informacji na temat czasu odpowiednich rytuałów niż w innych: PDM XIV zawiera w sobie aż dwadzieścia procent wszystkich odniesień do pory działania, PGM IV - szesnaście procent, PGM XIII - szesnaście procent, PGM III - dwanaście procent, PGM VII - sześć procent. Są to jednak wszystko papirusy o naj-większej liczbie wersów, procent zawartych w nich określeń dotyczących czasu w stosunku do całości zbioru nie pozwala więc na wysnuwanie żadnych wniosków. Na dodatkową uwagę zasługuje jednak PGM XIII - tekst ten jest świetnym przykładem niekonsekwencji w przekazywaniu wskazań co do czasu obrzędów magicznych.

Starożytni podejmowali się odprawiania rytuałów magicznych nie tyle z myślą, że w konkretnym momencie należy czcić danego boga lub demona, lecz z przekonaniem, że w danej chwili można z nim nawiązać bliższą relację i może on być bardziej pomocny w wypełnieniu celu, na którym nam zależy - taki wniosek nasuwa się przede wszystkim po obserwacji stosunku do planet, które były przecież uznawane czasami za bogów, a przynajmniej za ich symbol. Obliczano i wypatrywano ich korzystnego ustawienia, by wywarły oczekiwany wpływ na działania maga lub medyka, nie zaś po to, by ustalić moment, w którym należy oddawać im cześć. Taki sam wniosek można wysnuć również na podstawie niektórych zaklęć do Heliosa wypo- 
wiadanych o zachodzie. Wątek nocnego pobytu boga w podziemiach traktowany jest przez maga utylitarnie - do boga należy zwrócić się przed jego zniknięciem za horyzontem, bo za chwilę będzie miał kontakt z duchami, które są potrzebne do wykonania konkretnego zadania.

Przy zwrotach do bóstw solarnych i lunarnych, zwłaszcza o wschodzie i zachodzie Słońca, nie zawsze można mieć pewność, czy w zaklęciu zwrot do Słońca jest kierowany do boga, czy do Słońca jako ciała niebieskiego bądź do wschodu/zachodu jako kierunku. ${ }^{67}$ Imię Heliosa i określenia Słońca mogą być w końcu traktowane wymiennie w różnych znaczeniach.

W PGM da się wyodrębnić grupy zaklęć i rytuałów o wspólnych cechach oraz zbliżonym czasie wykonywania. Jednak poza wschodem Słońca trudno o stwierdzenie pewnych i jasnych zależności między rodzajem magii i rytuału a czasem odprawiania. Próba wbrew pozorom jest mała. Może być jednak wartościowym porównaniem dla informacji ze źródeł literackich. Thesaurus cultus et rituum antiquorum wskazuje, że jedną z różnic pomiędzy magią a religią jest to, że osoby praktykujące magię same decydowały, kiedy rytuały mają być przeprowadzone, podczas gdy akcje religijne powinny być wyko-nywane zgodnie $\mathrm{z}$ ustalonymi zasadami ${ }^{68}$. Na pewno jednak istniały jakieś - niepisane lub niezachowane do naszych czasów - reguły znane magom. Być może właśnie ich istnienie i powszechna znajomość jest powodem, dla którego w wielu instrukcjach magicznych nie ma odniesienia do czasu. Poza powszechnymi przekonaniami o wpływie planet na Ziemię, każdy mag posiadał podstawową wiedzę również i o tym, które działania w jakim czasie mają większę szansę powodzenia. Mimo dowolności we wskazywaniu pory odpowiedniej dla danych praktyk można dostrzec ślady istnienia lub chociaż prób ustalenia pewnych zasad, które miały wpłynąć na zwiększenie skuteczności działań magicznych.

Joanna I. Cel

ORCID: 0000-0003-1451-5569

Wydział Historii, Uniwersytet Warszawski

ji.cel@uw.edu.pl

${ }^{67}$ Cohn, „P.Mich 3404” (cyt. w przyp. 14), s. 245.

${ }^{68}$ ThesCRA, s. 285. 


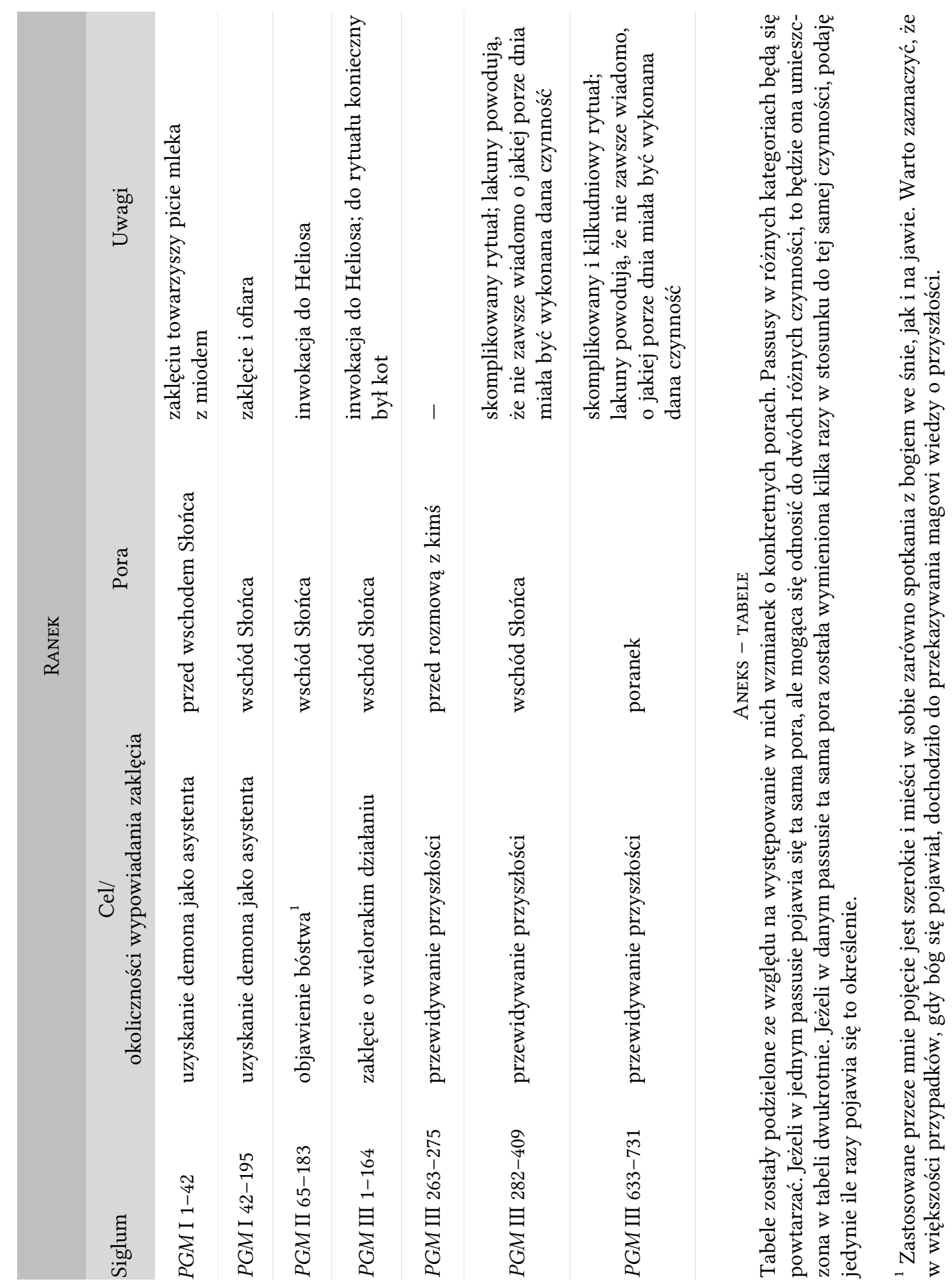




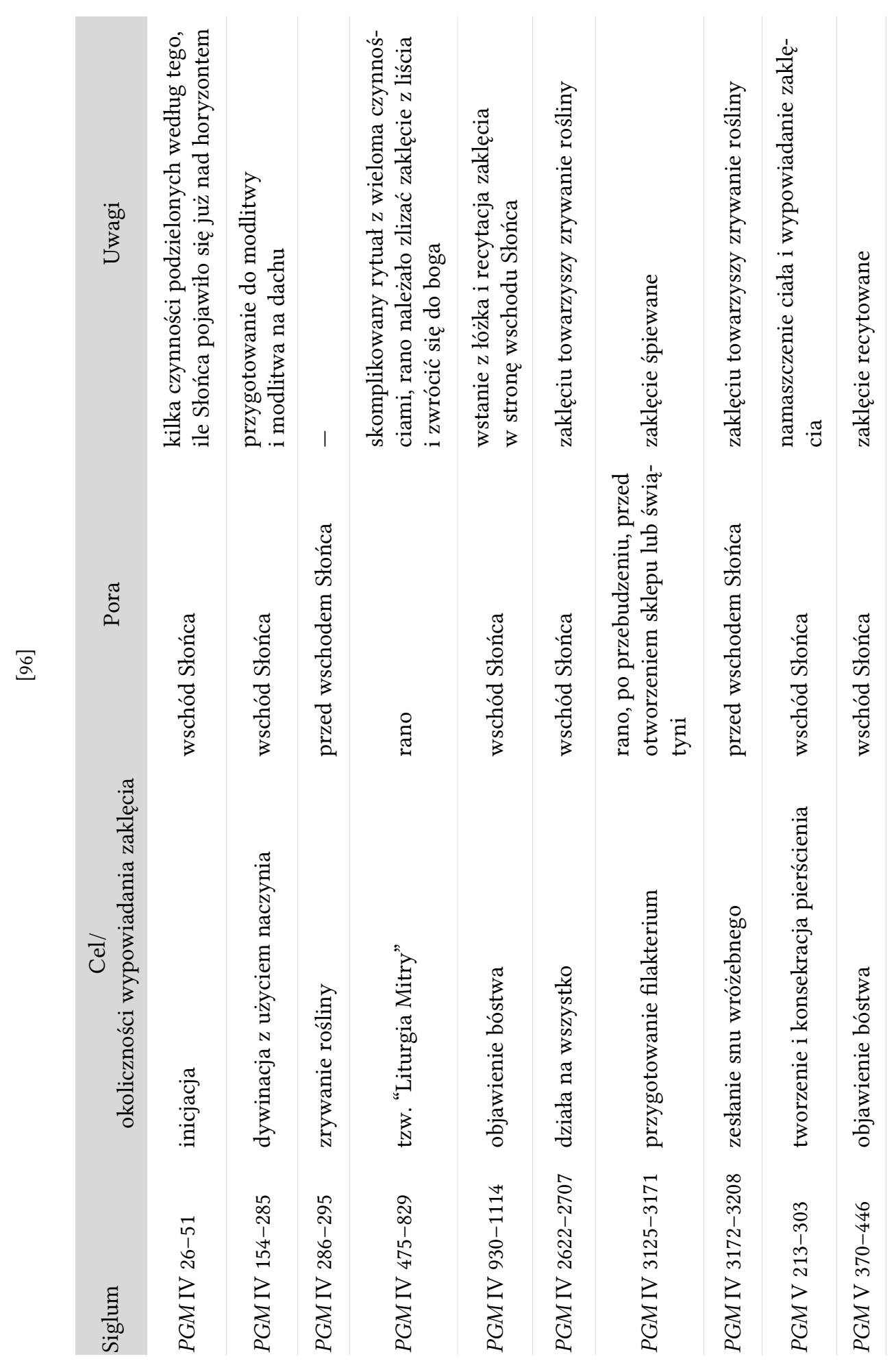




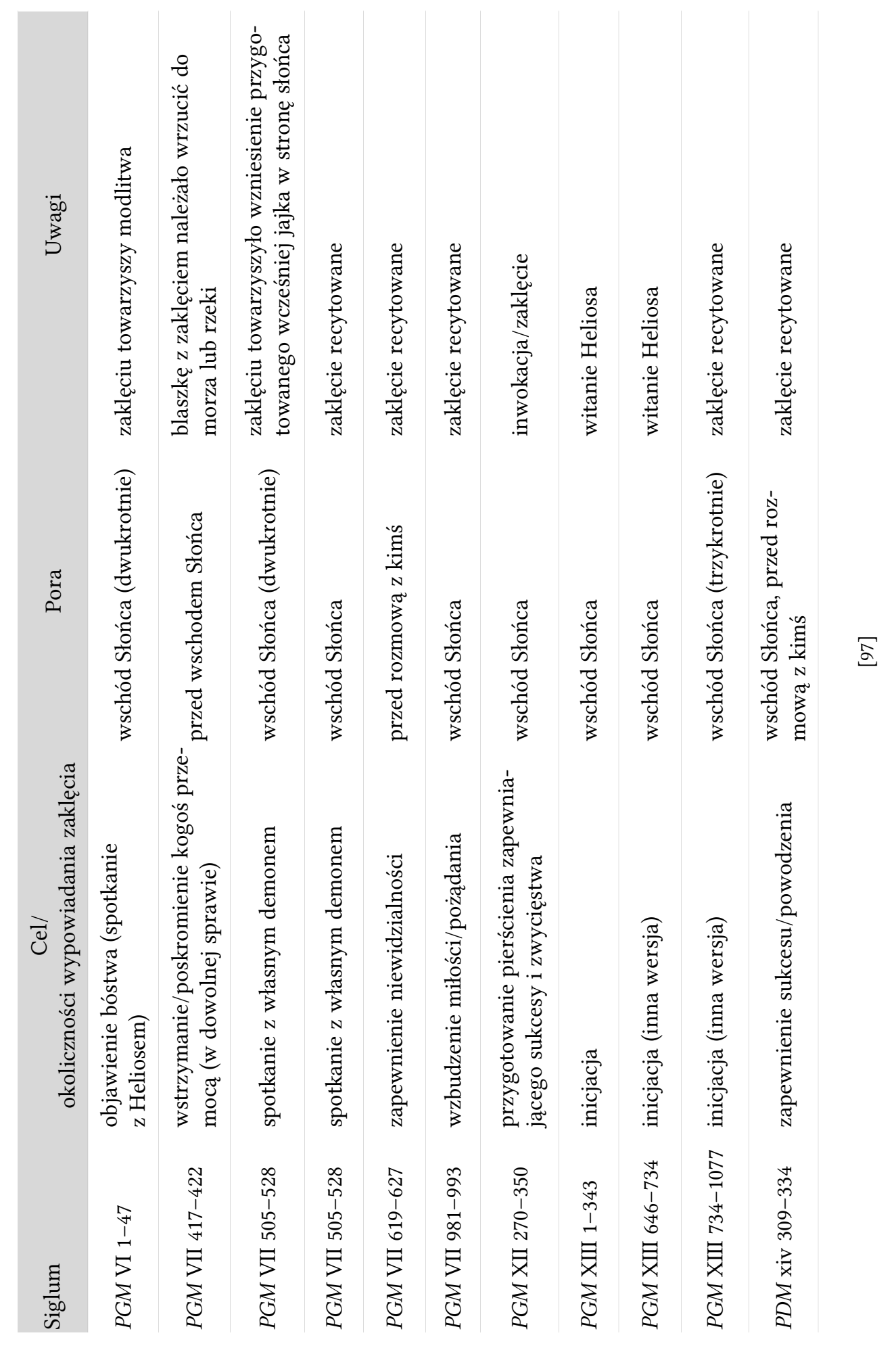




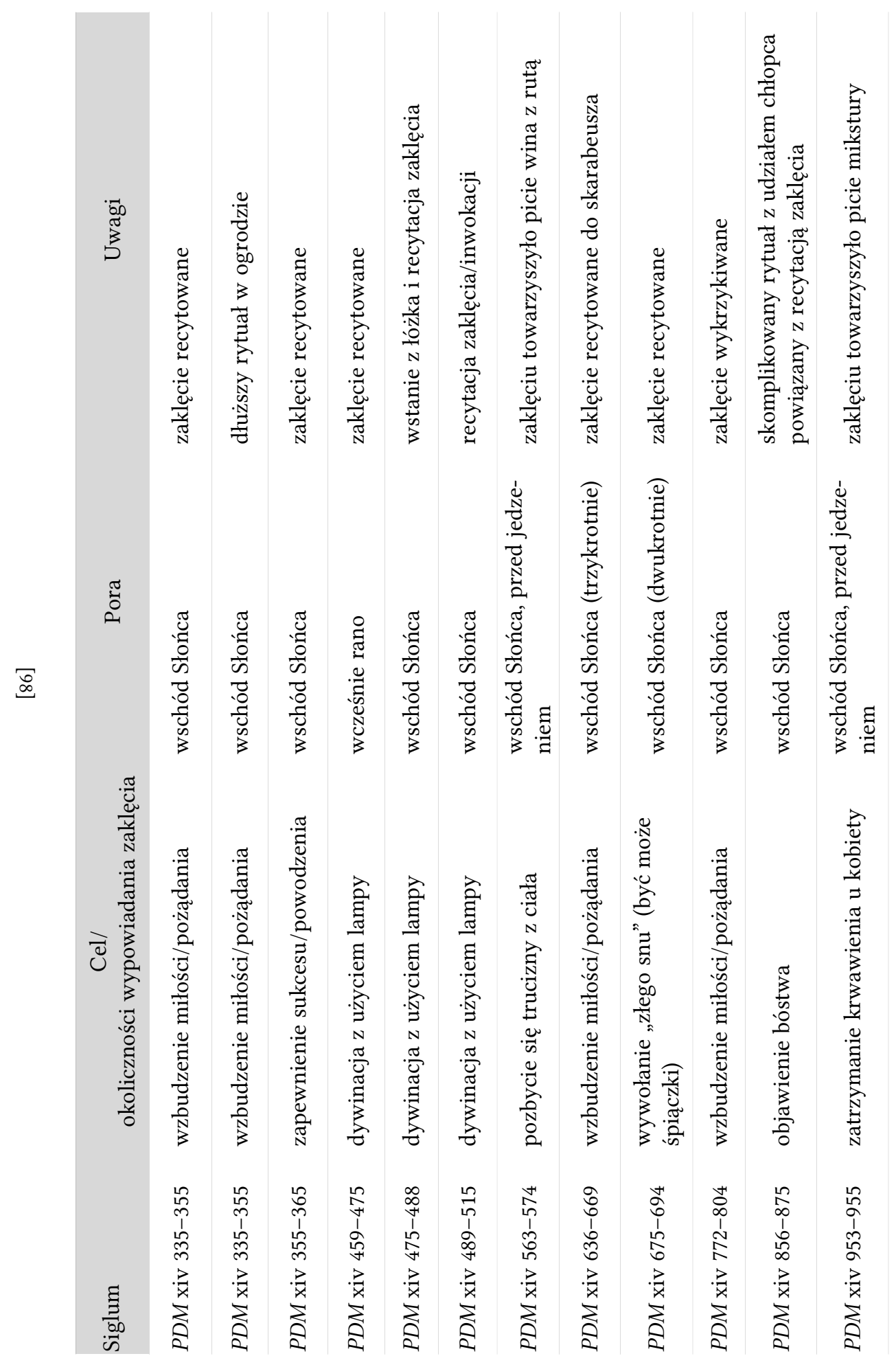




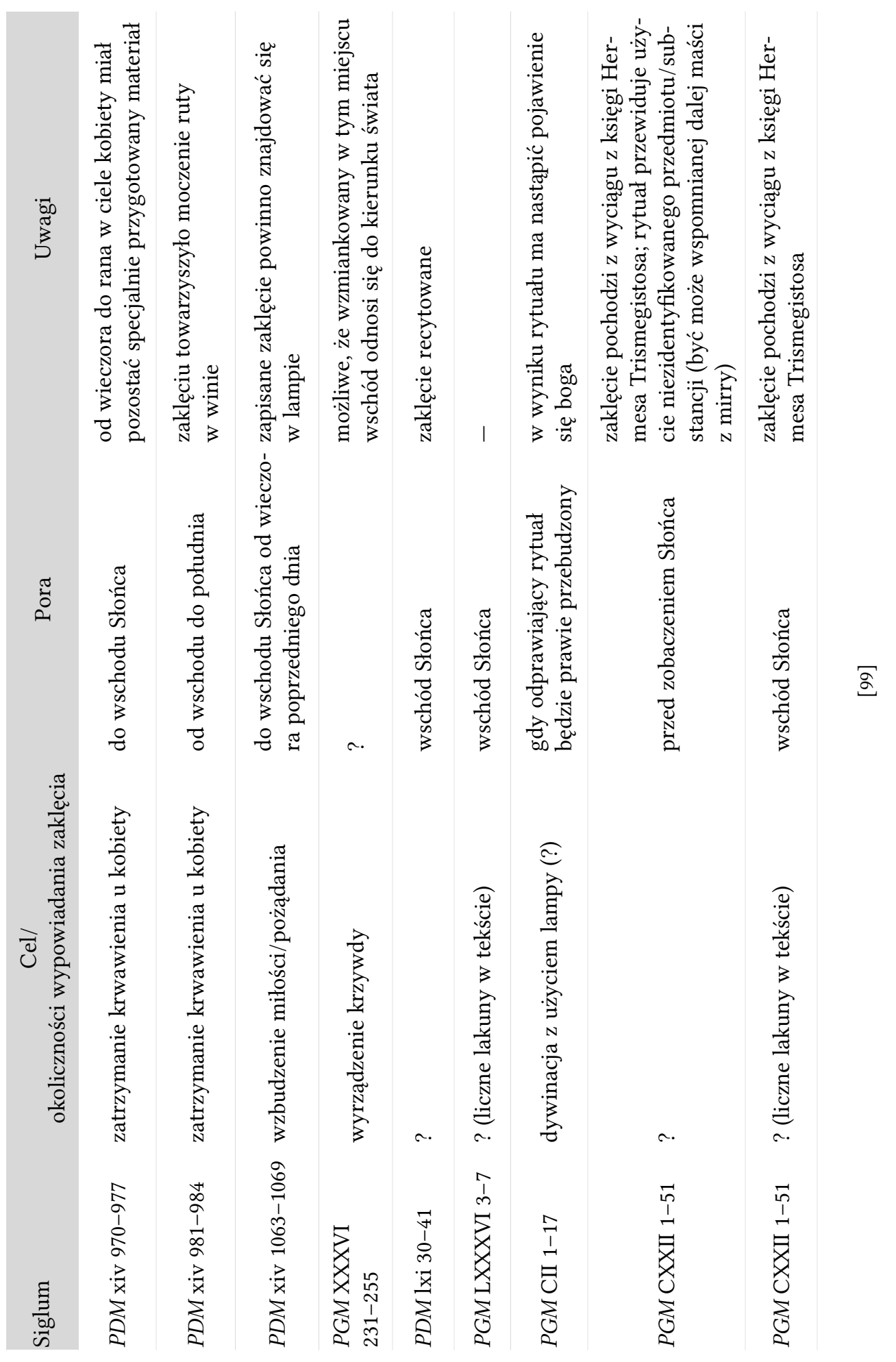




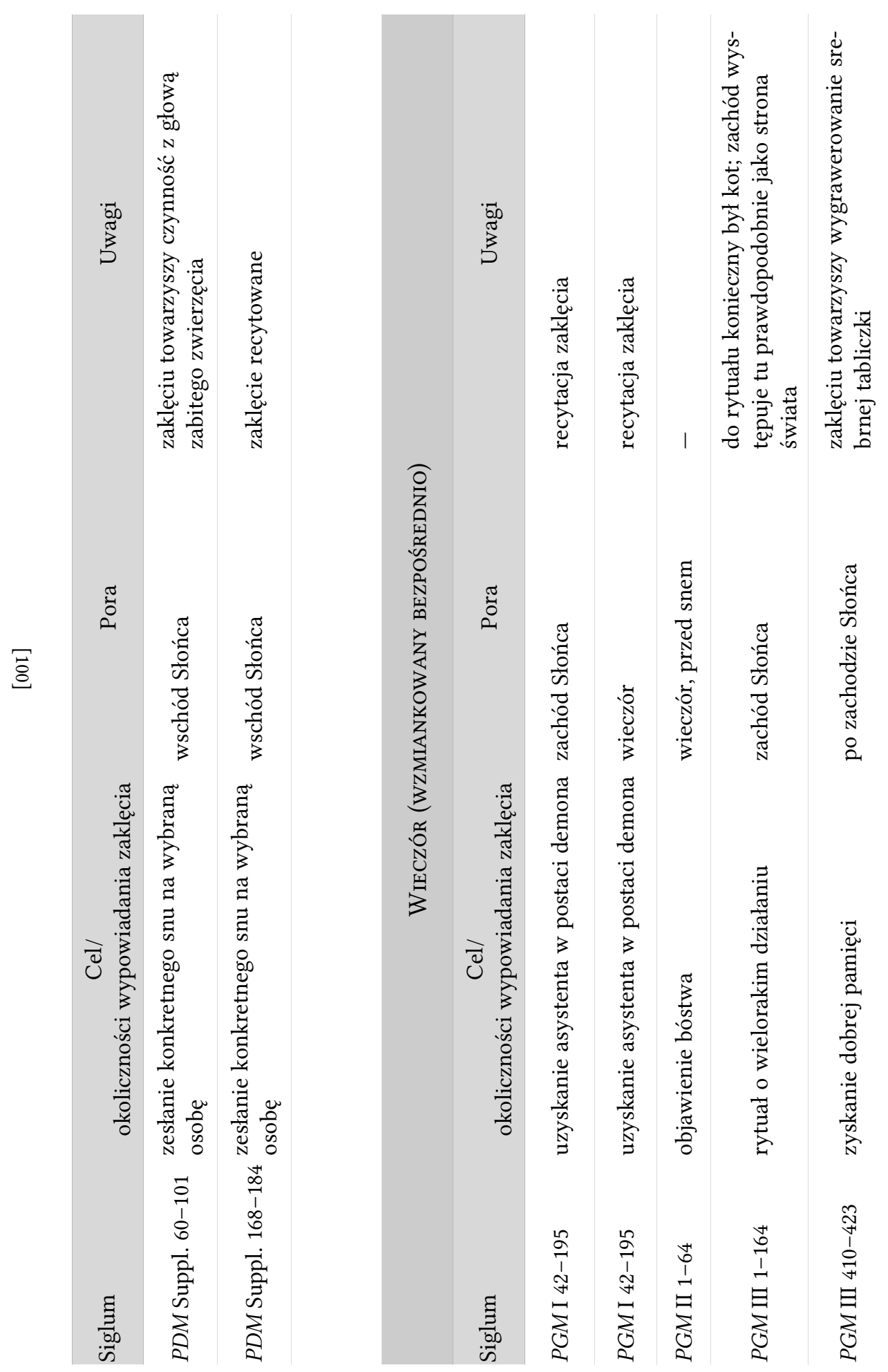




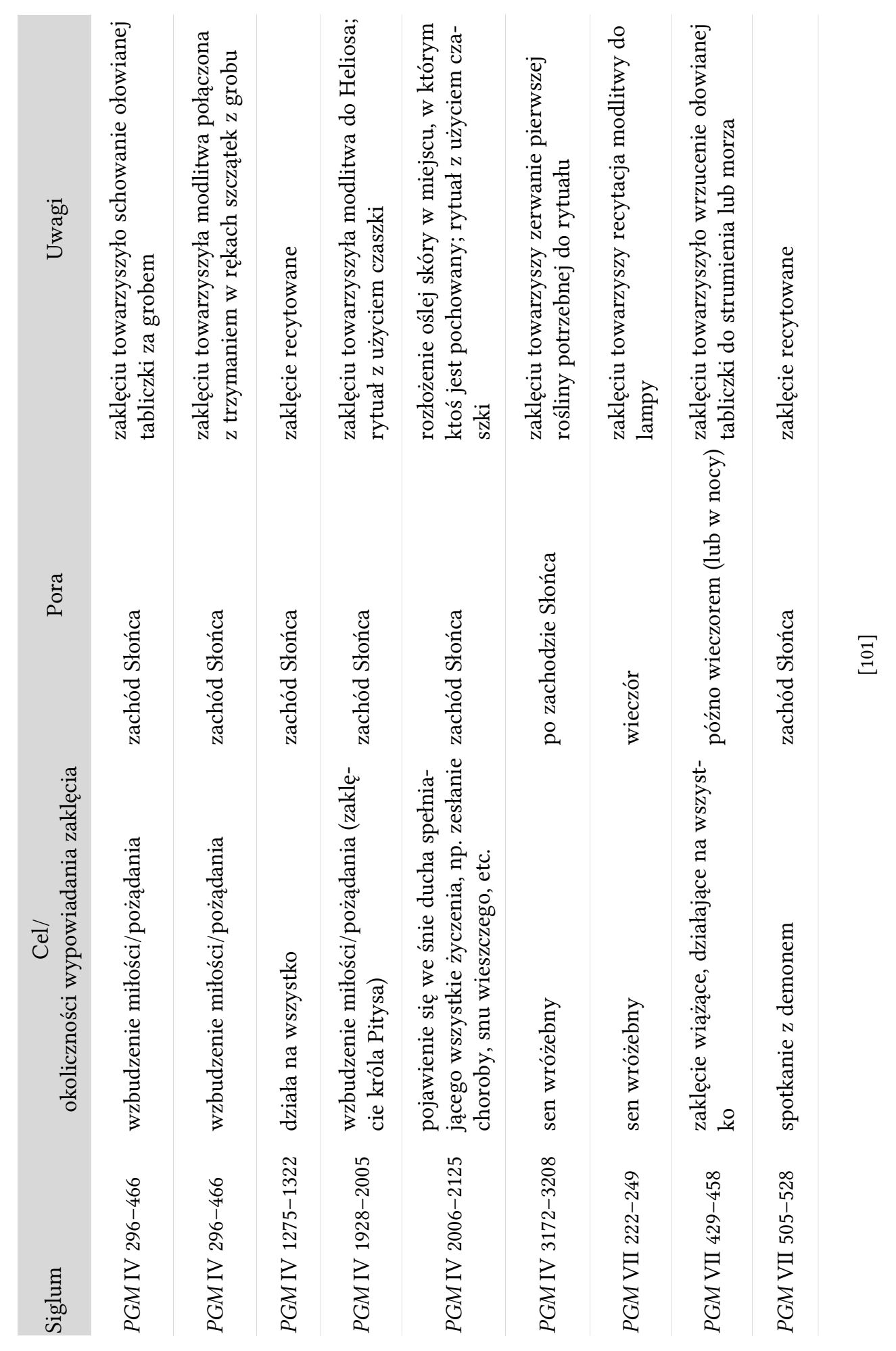




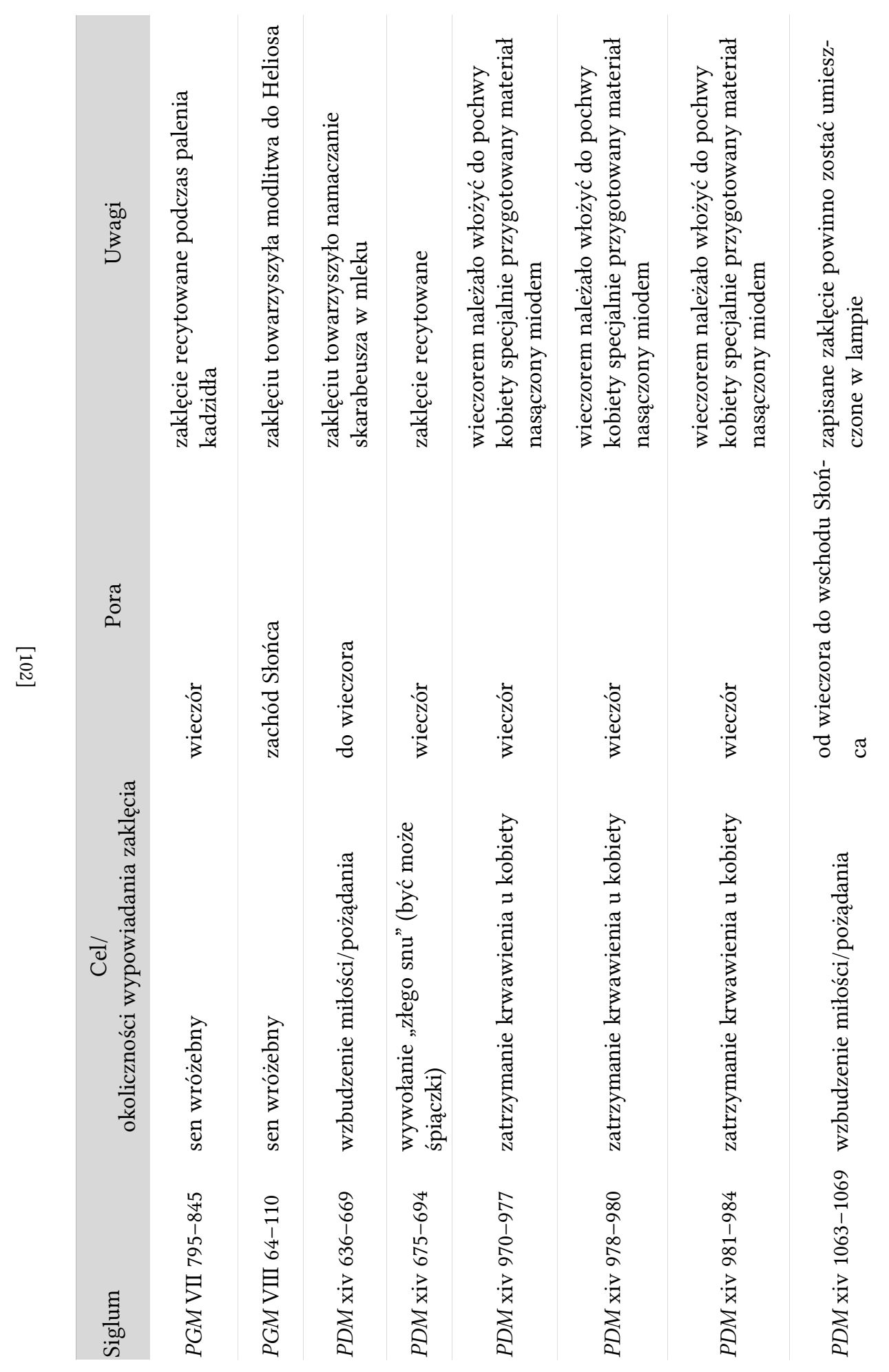




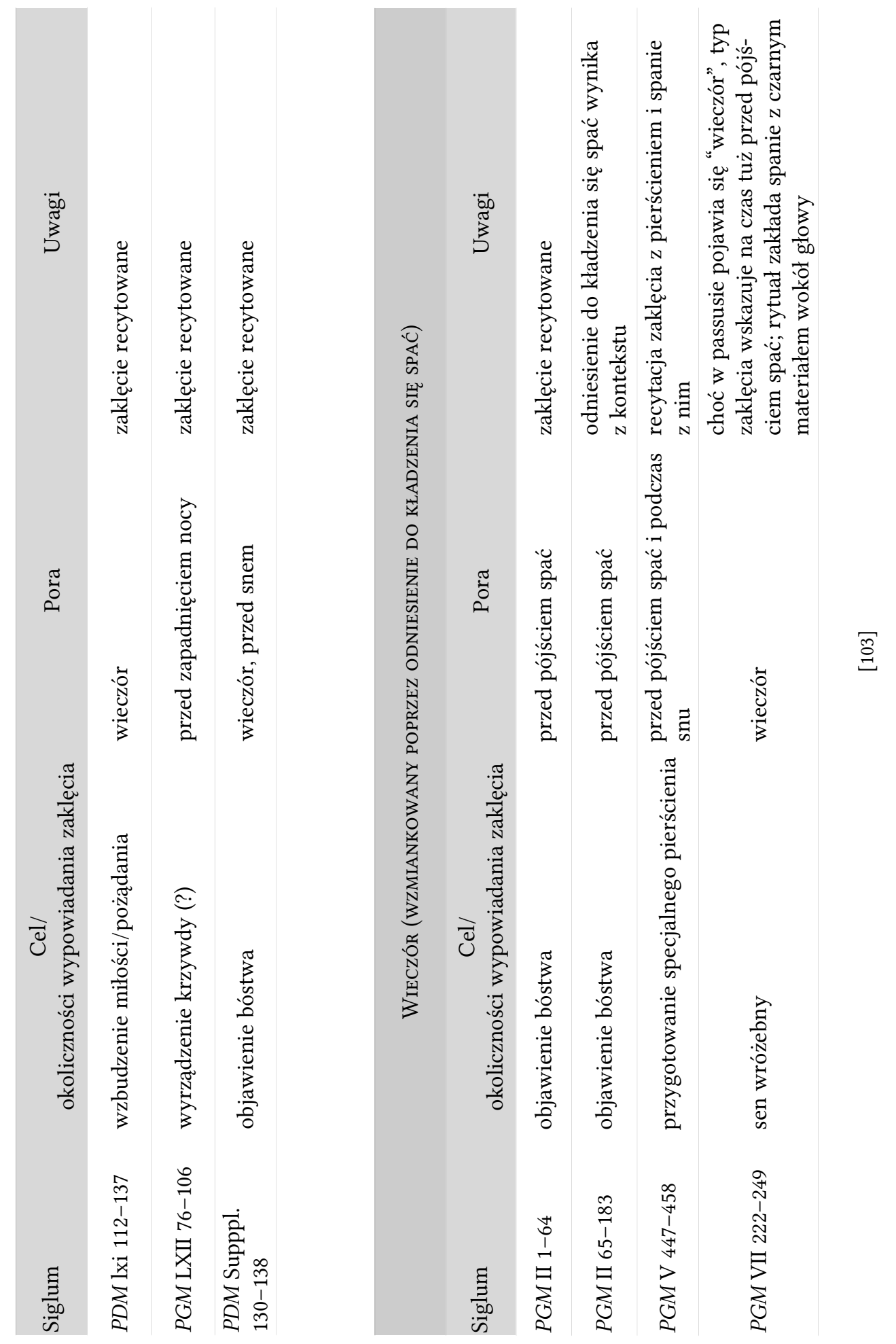




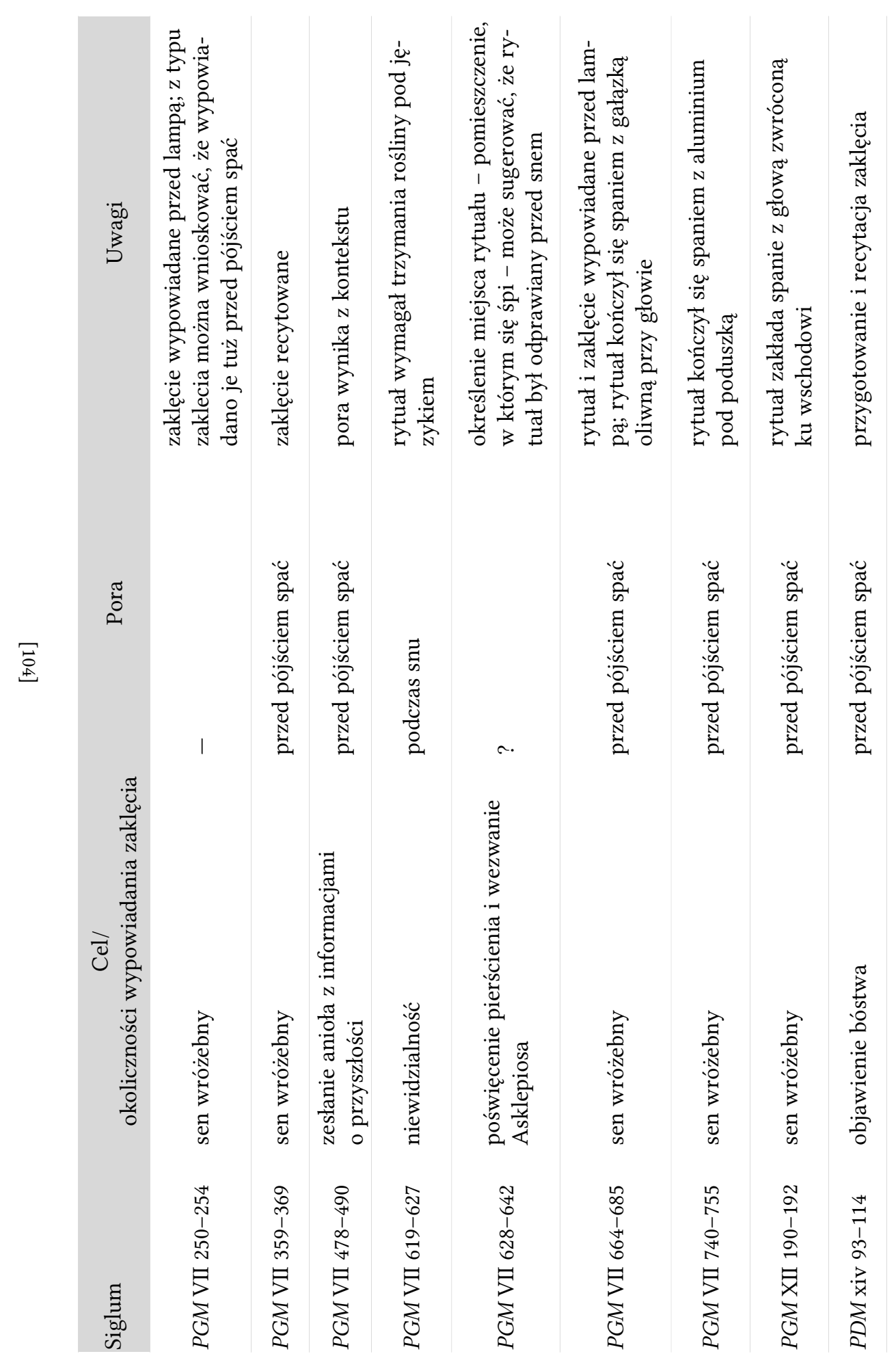




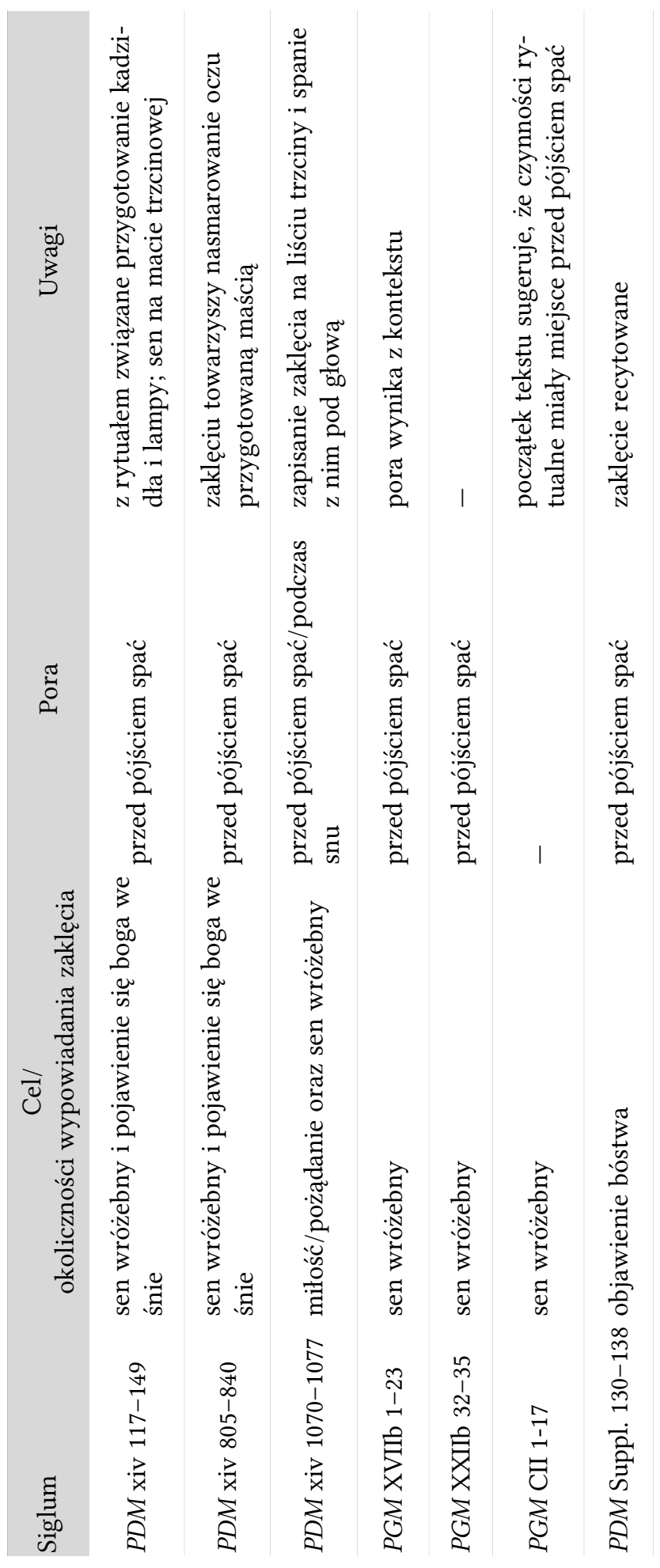




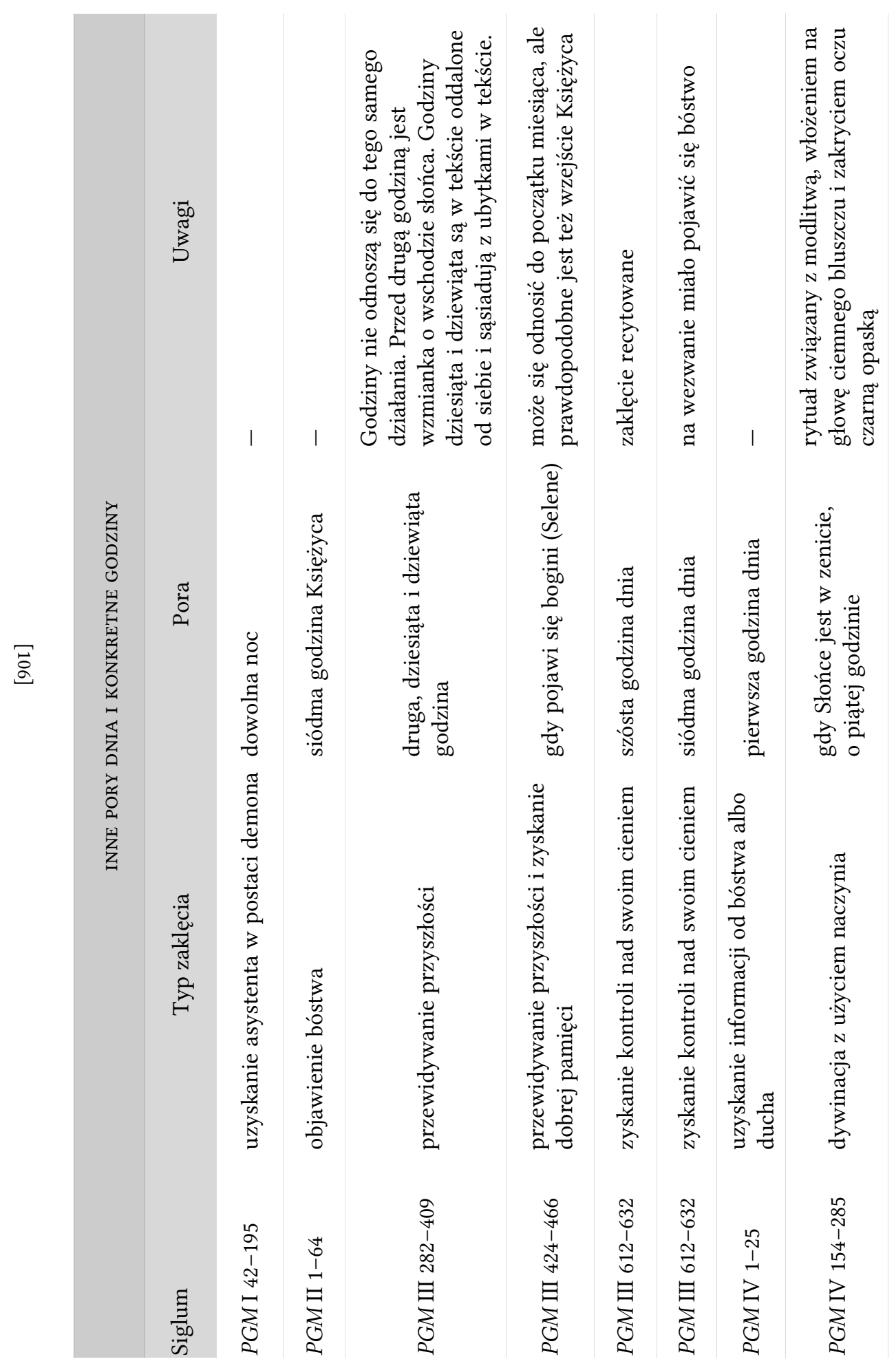




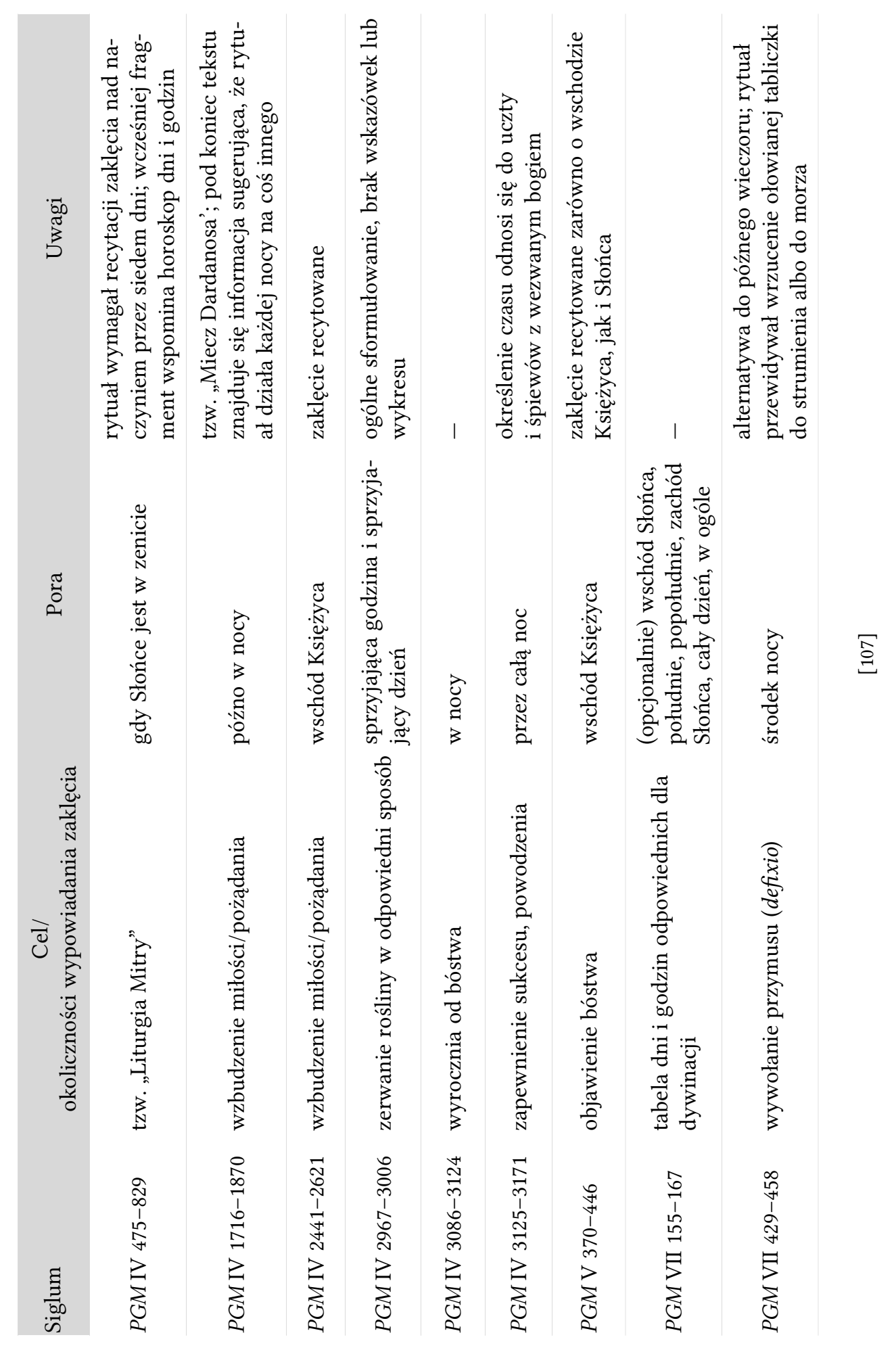




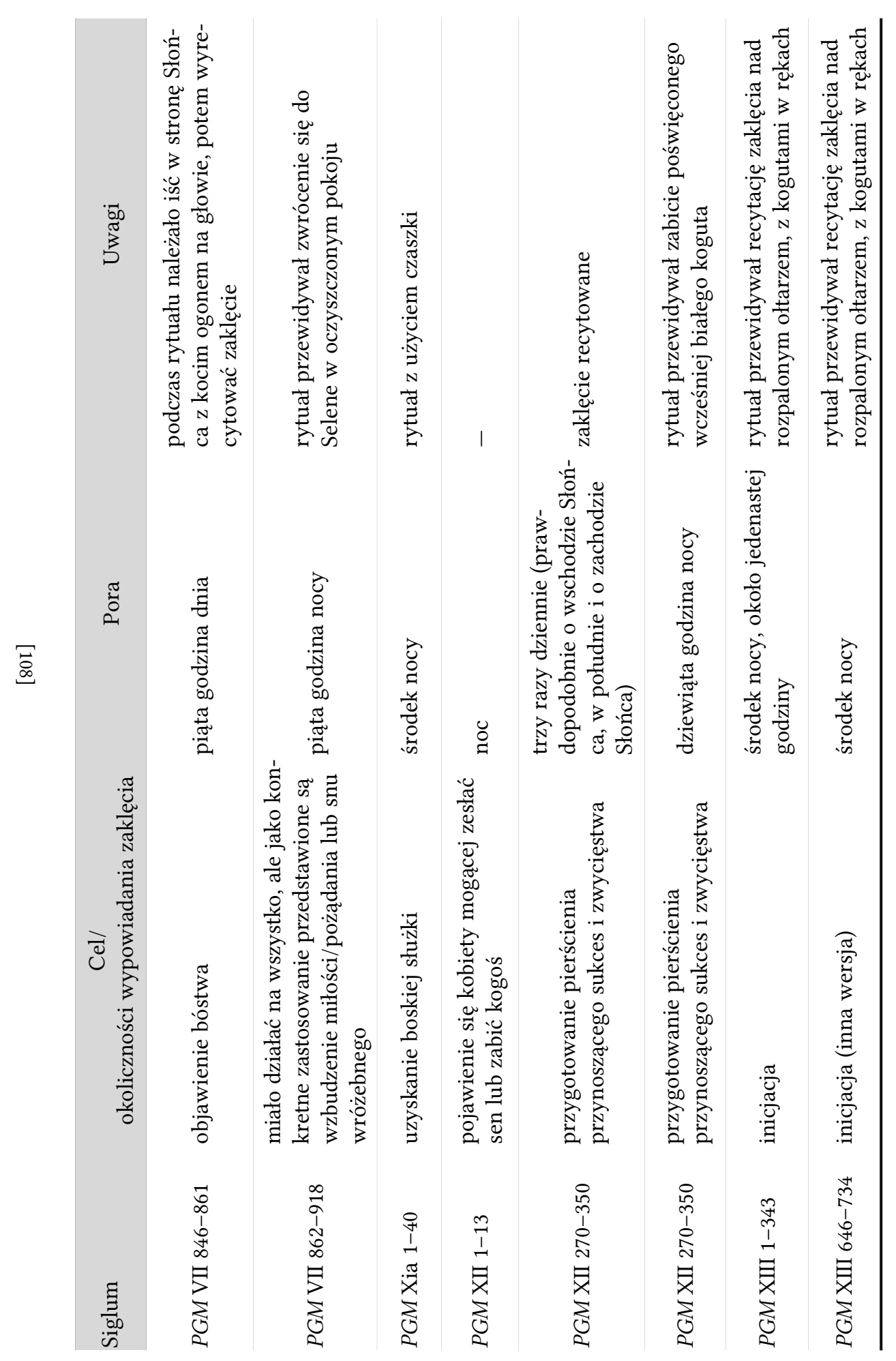




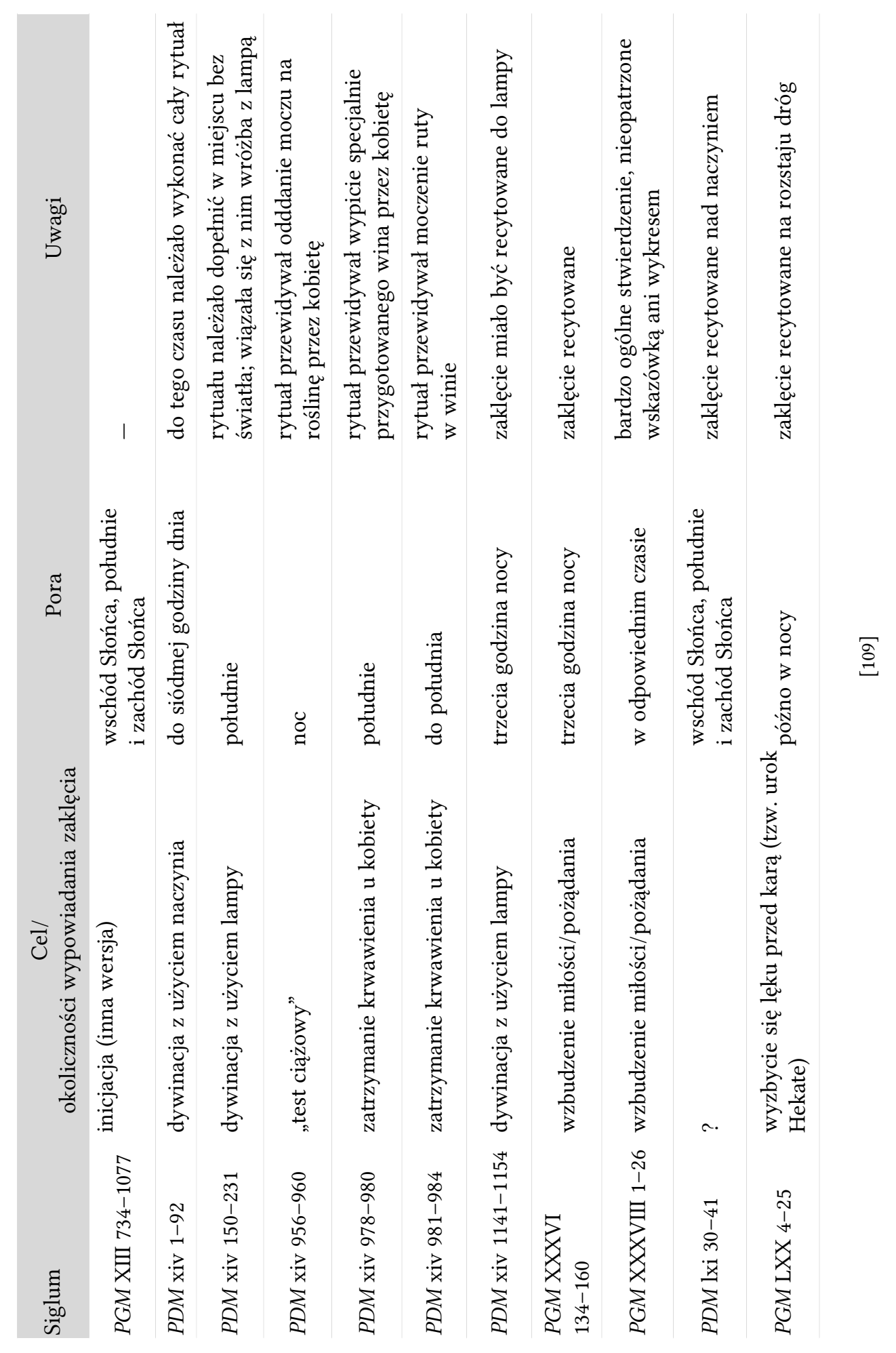




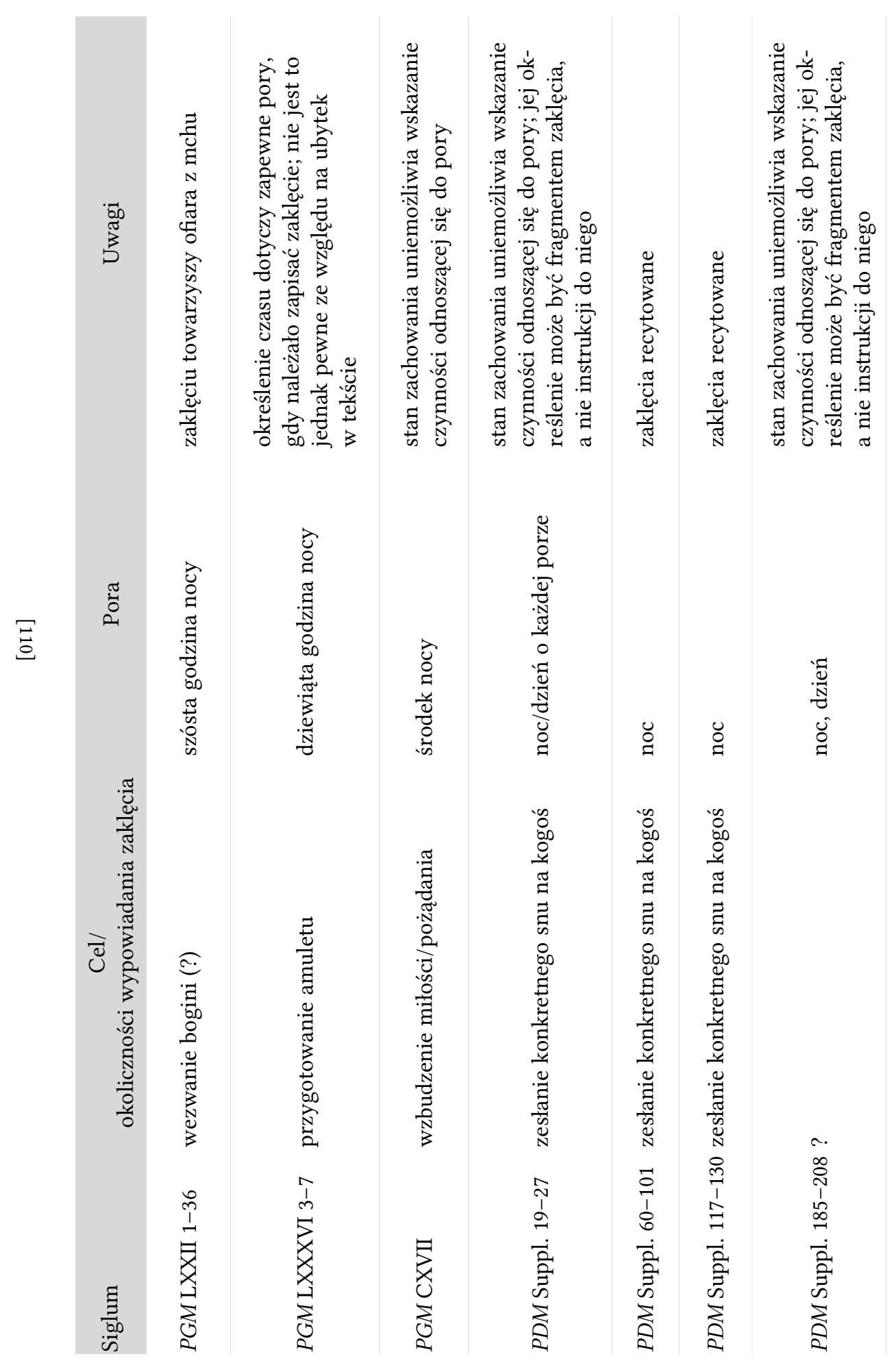




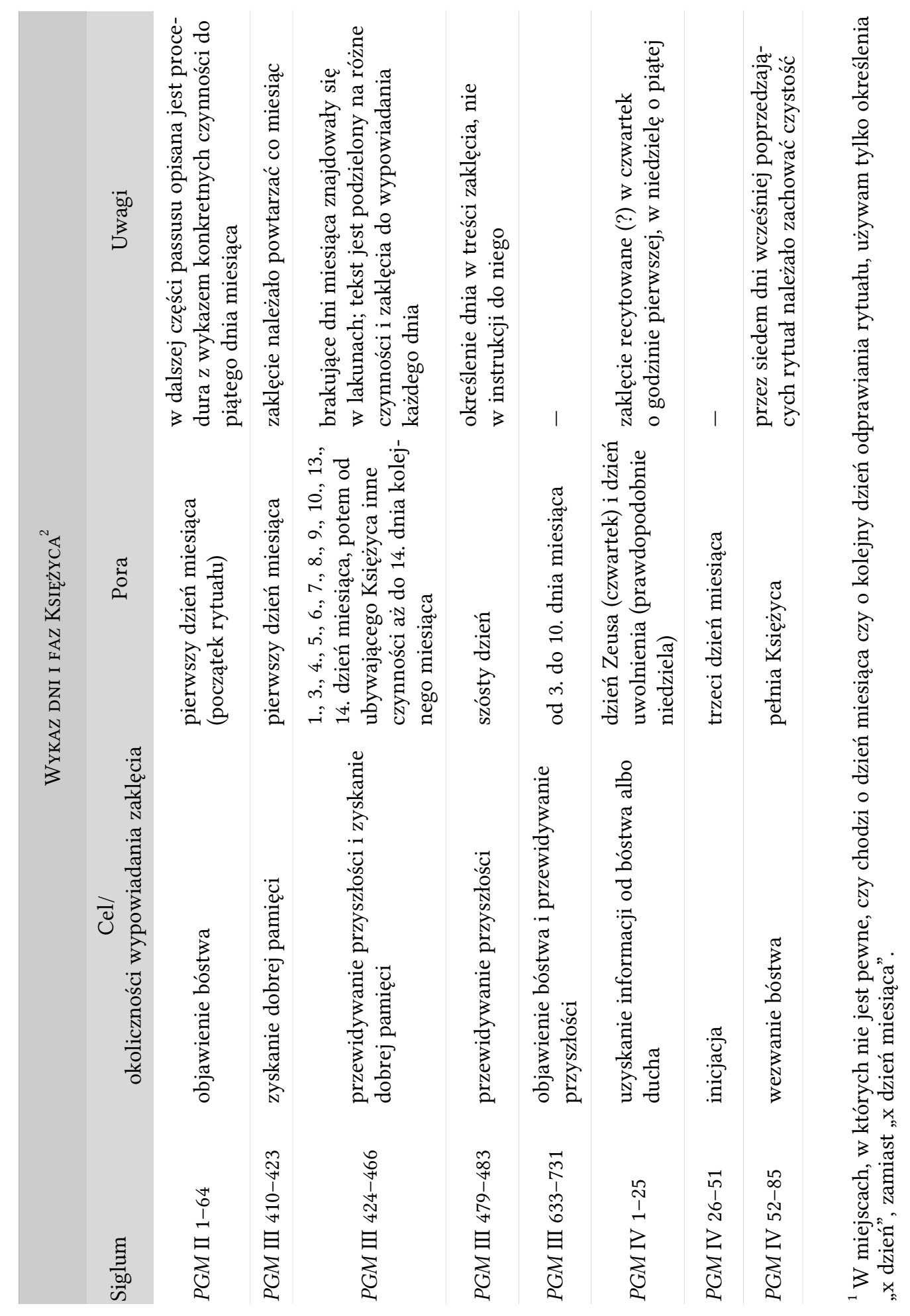




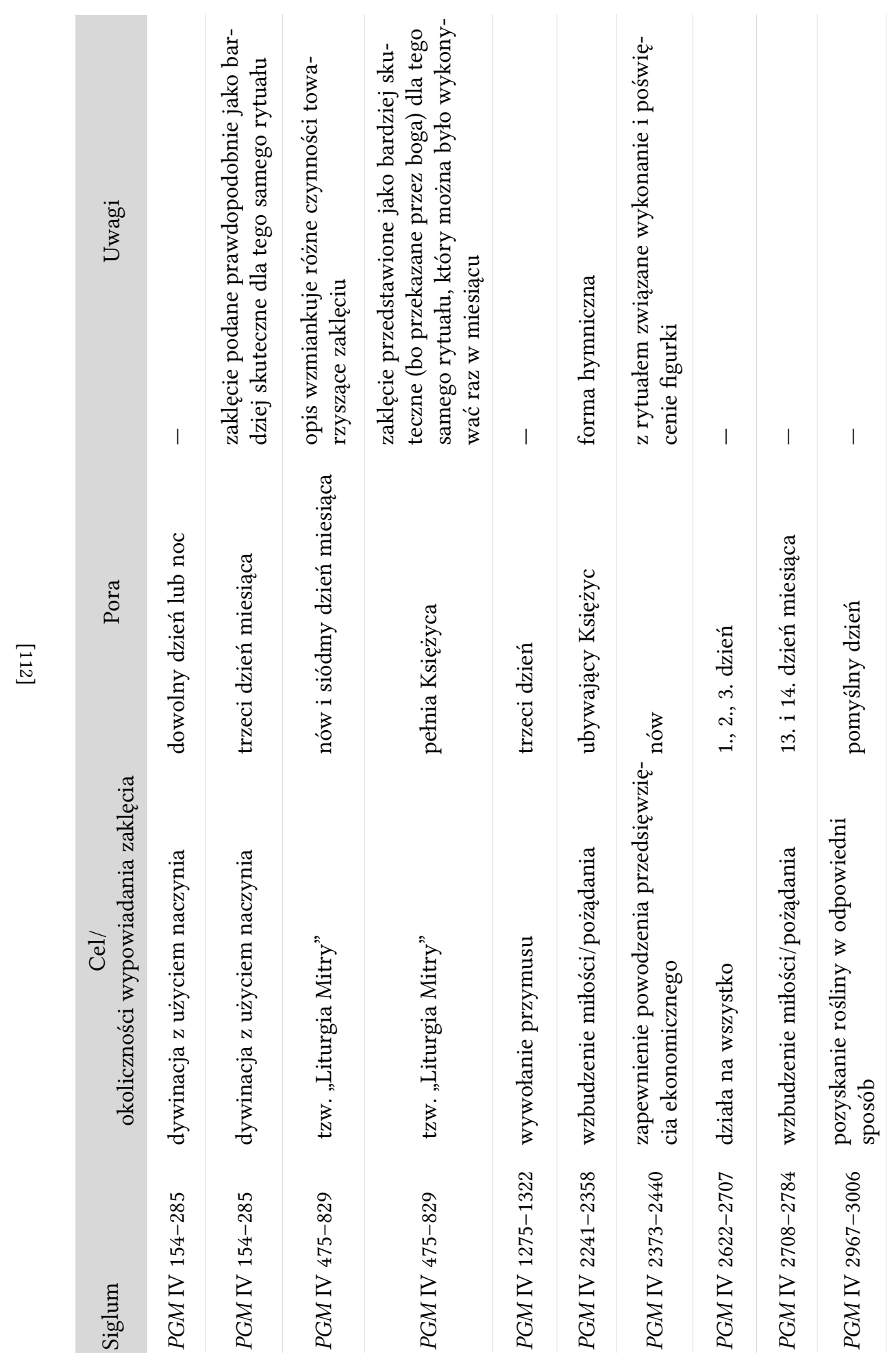




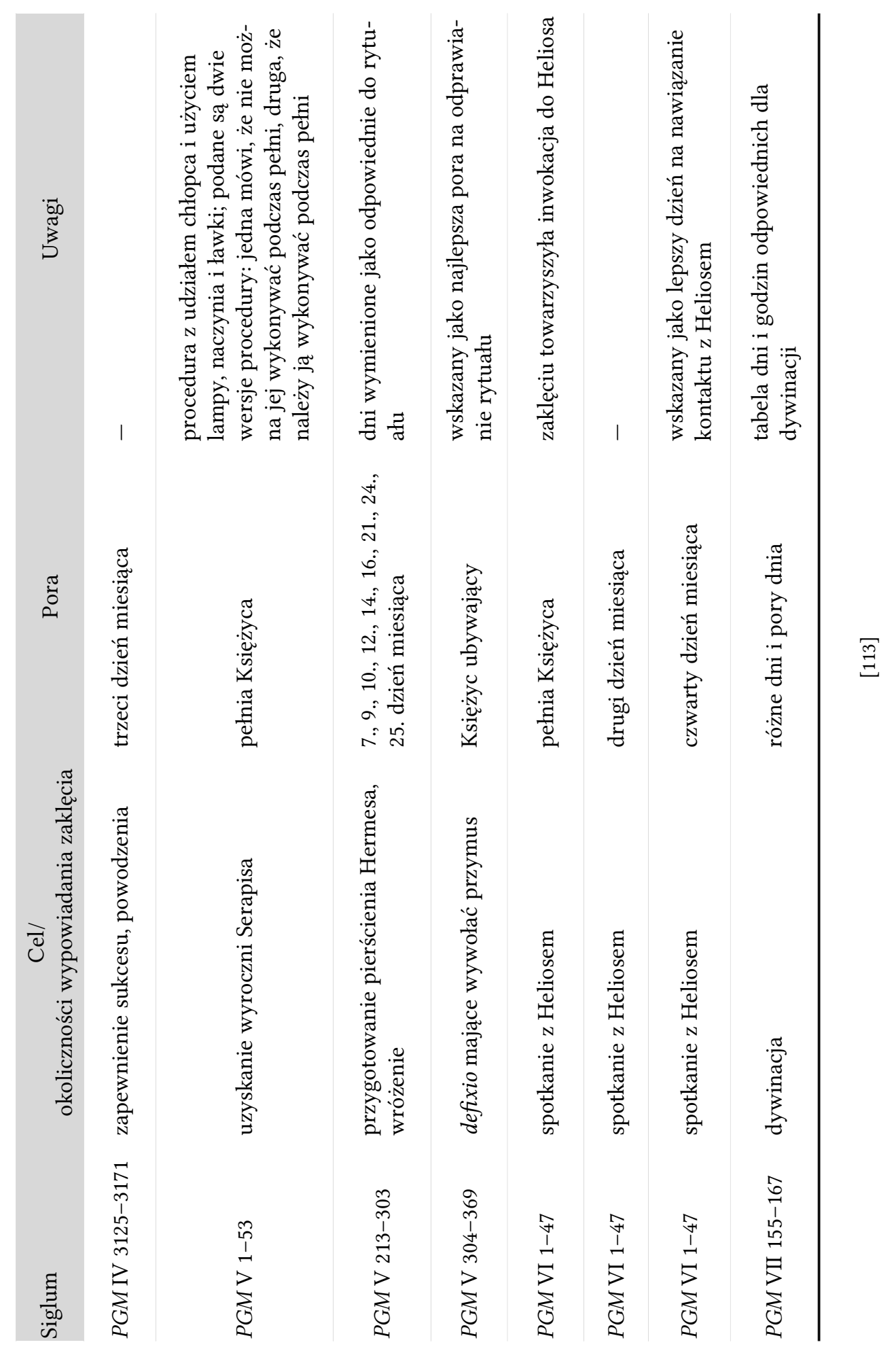




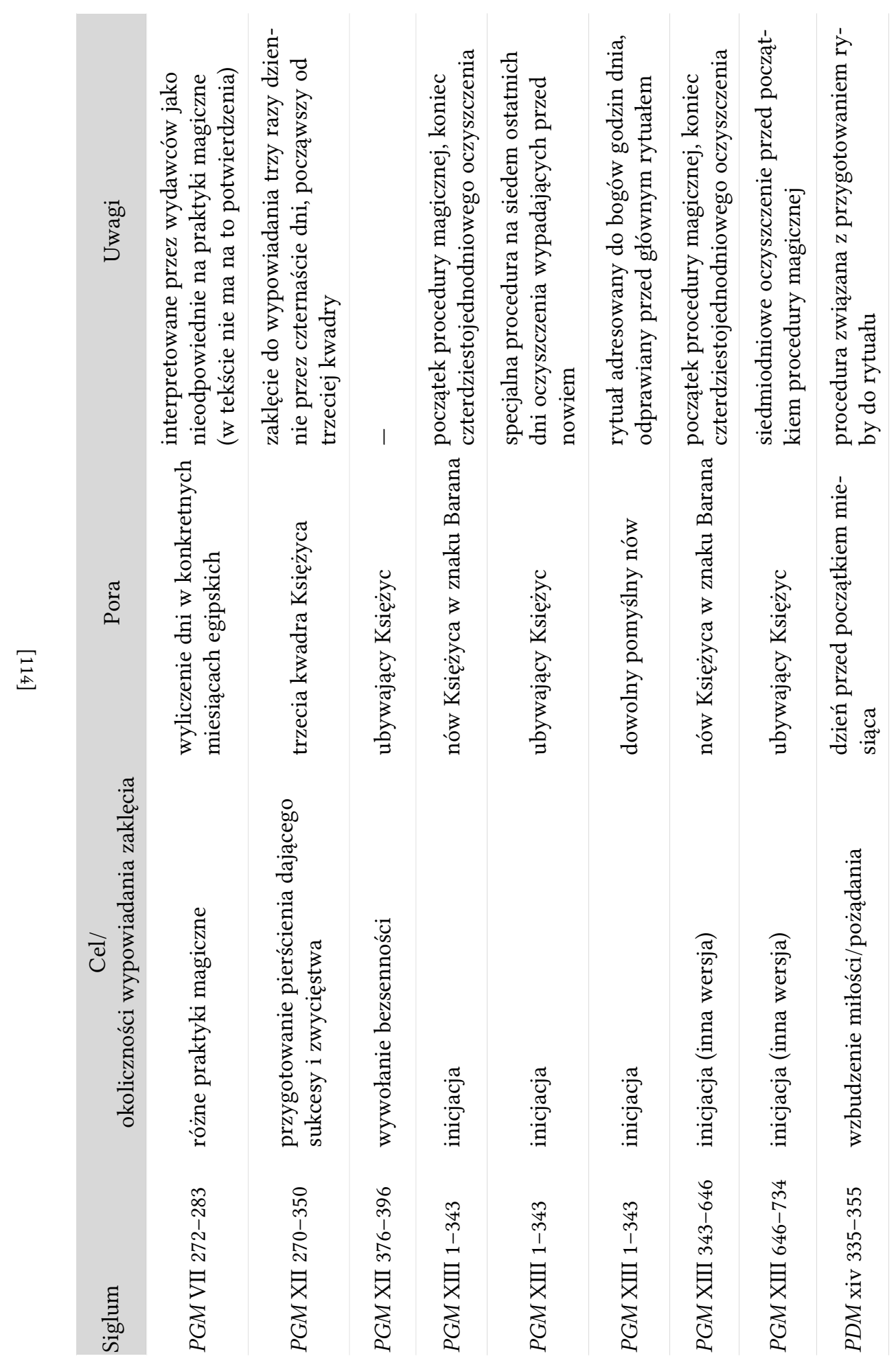




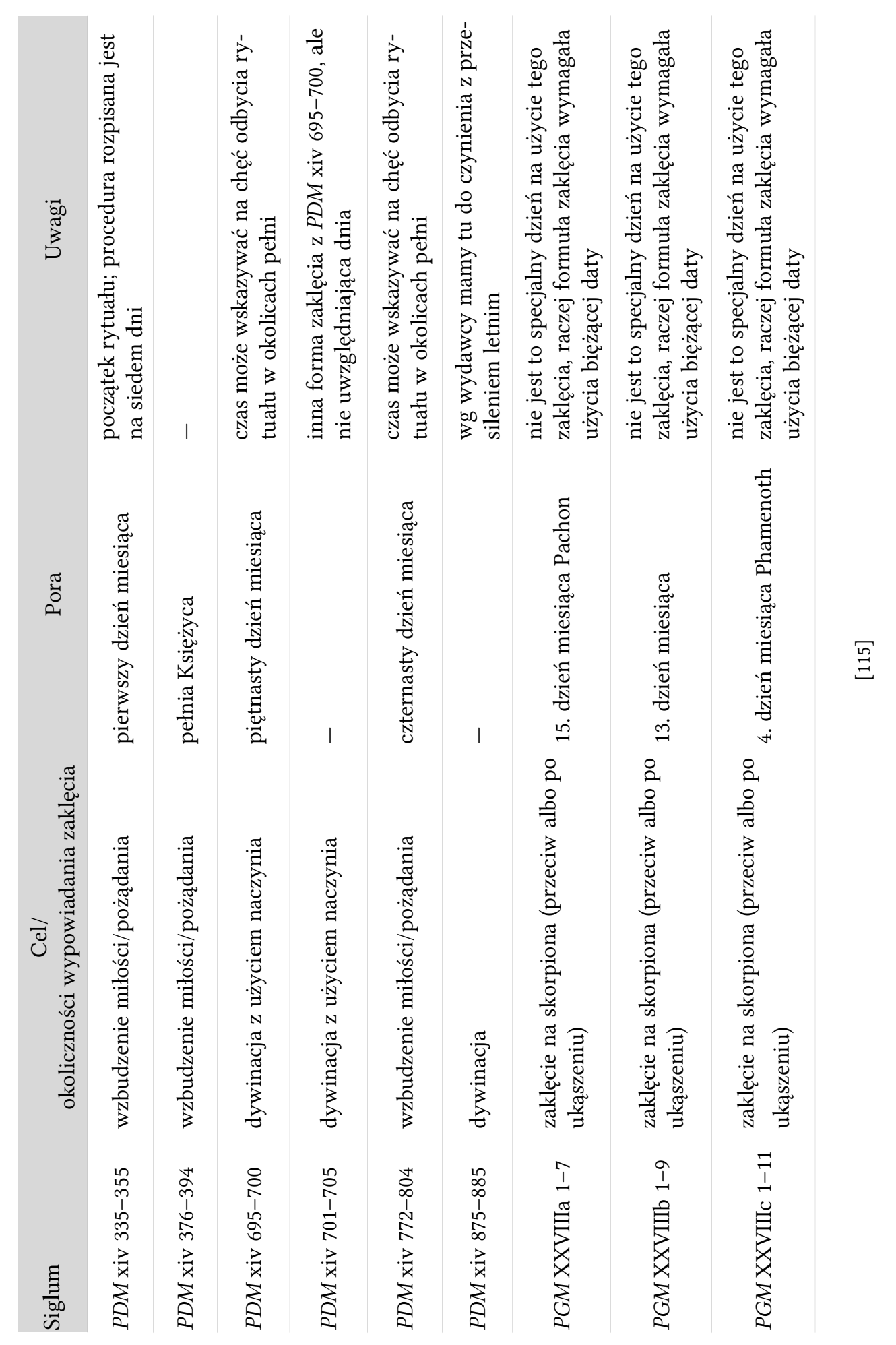




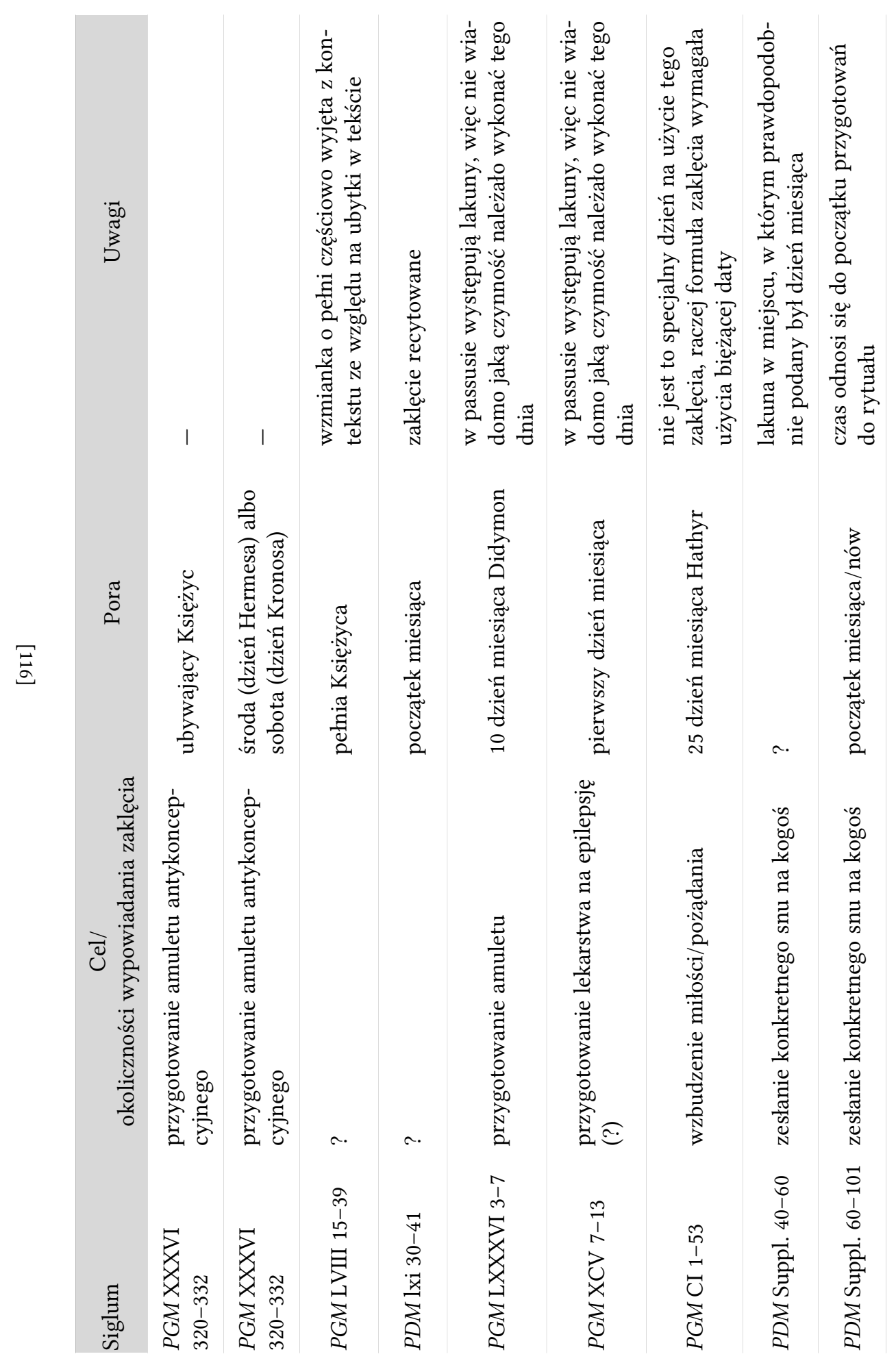




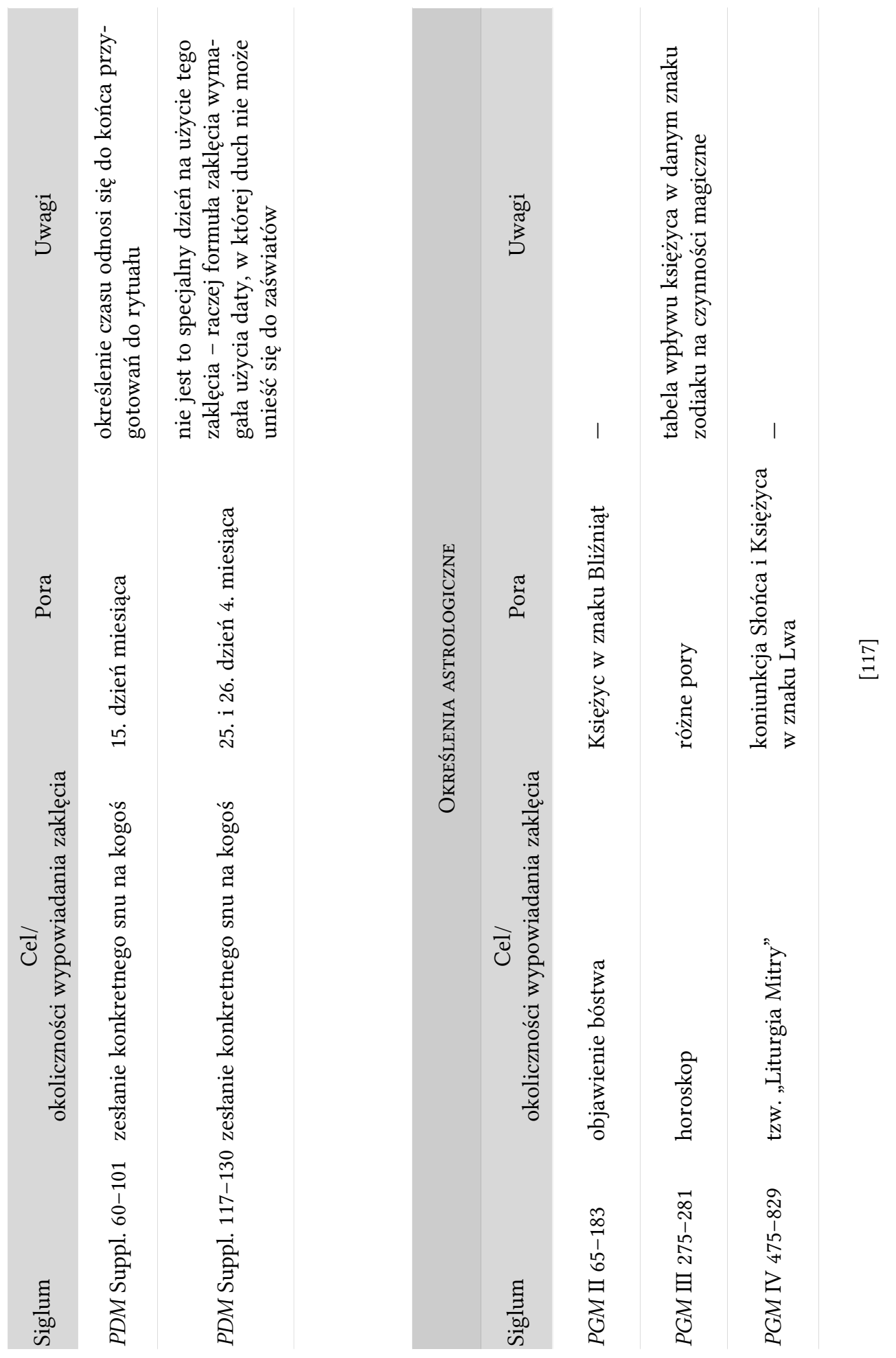




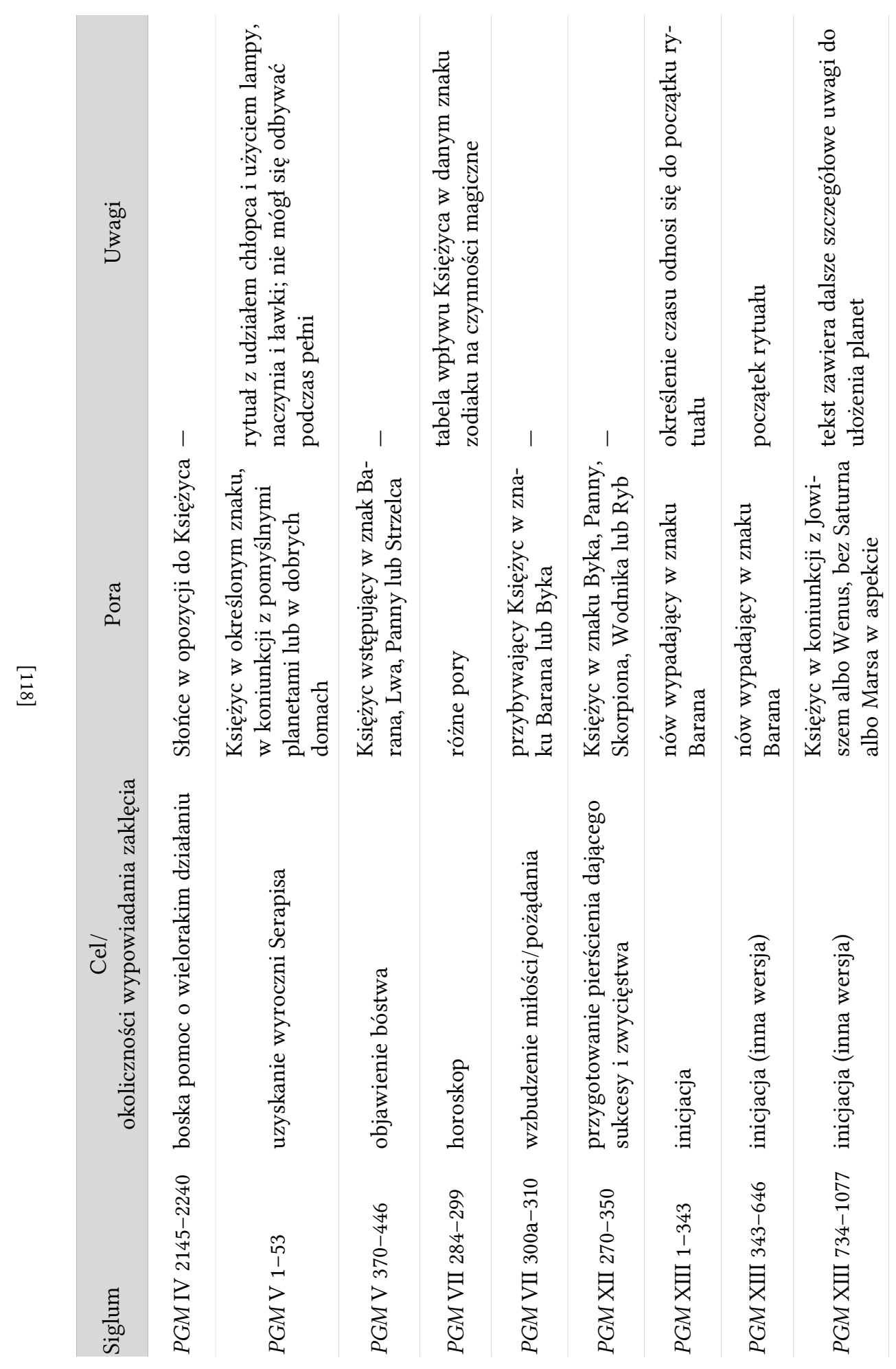




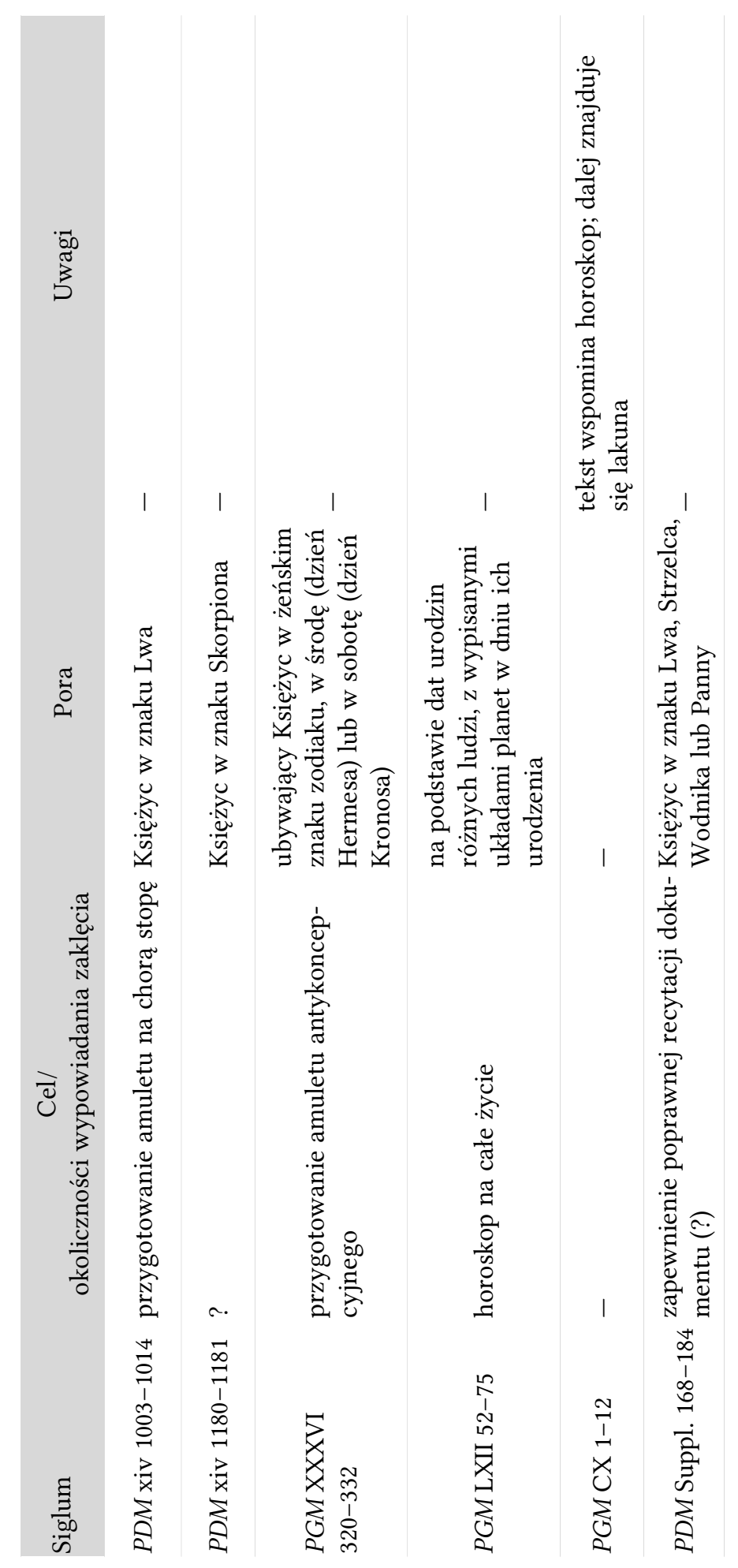


KwESTIA PORY KWESTIA PORY ODPRAWIANIA RYTUAŁÓw W ŚWIETLE TZW. GRECKICH PAPIRUSÓW MAGICZNYCH

\begin{abstract}
Abstrakt
Artykuł porusza kwestię czasu przeprowadzania procedur magicznych wedle instrukcji zawartych w Papyri Graecae Magicae oraz Papyri Demoticae Magicae. Analizowane pory dzielę na trzy główne grupy: pory dnia, okres miesiąca, odniesienia astrologiczne. Ponadto wskazuję najbardziej odpowiedni czas na rytuały magiczne oraz, tam, gdzie to możliwe, powiązania między rodzajem uprawianej magii oraz porą. W omawianych papirusach występuje około 210 wzmianek na temat czasu. Nie pozwala to na wiarygodne wykorzystanie metod statystycznych, daje jednak podstawę do przyszłego porównania danych z papirusów z literackimi opisami praktyk magicznych. Artykuł podkreśla ważny, chociaż niedoceniany, aspekt magii udowadniając, że należy zwracać uwagę, nie tylko gdzie i jak odbywały się rytuały magiczne, ale również kiedy.
\end{abstract}

Słowa kluczowe: Papyri Graecae Magicae, Papyri Demoticae Magicae, magia antyczna, czas, wschód/zachód Słońca

The Question of THE TIME OF PERforming RituAls IN THE LIGHT OF THE GReEK Magical PAPYRI

\begin{abstract}
The paper discusses the time of magical actions according to the practical instructions in the magical papyri. I distinguish three groups of time periods: the time of the day, the time of the month, and astrological references. I do not just try to indicate the most suitable time for magical rituals, but to find possible connections between the type of magic and the time. The c.210 mentions of time in the Papyri Graecae Magicae and do not allow for a reliable use of statistical methods but give a base for a future comparison of data from the instructions with the literature. The text highlights an important but overlooked aspect of magical rites, namely that it is not only important where and how the action was taking place, but also when.
\end{abstract}

Keywords: Papyri Graecae Magicae, Papyri Demoticae Magicae, ancient magic, time, sunrise/sunset 